JOINT TRANSPORTATION RESEARCH PROGRAM

FHWA/IN/JTRP-2010/21

Final Report

PERFORMANCE OF INDIANA'S SUPERPAVE HMA MIXTURES

Ayesha Shah

Rebecaa McDaniel

April 2011 


\section{TECHNICAL Summary}

INDOT Research

Technology Transfer and Project Implementation Information

TRB Subject Code:

Publication No.: FHWA/IN/JTRP-2010/21, SPR-2417

April 2011

Final Report

\section{PERFORMANCE OF INDIANA'S SUPERPAVE HMA MIXTURES}

\section{Introduction}

This project followed the performance of a number of hot mix asphalt paving projects for seven to eight years in an attempt to relate laboratory test results to field performance. First, a small scale study compared sampling locations, specific gravity test procedures and compaction devices used on samples from two projects, one with volumetric acceptance and one with non-volumetric acceptance, to determine the best combination to use for Part 2 of the study.
In Part 2, 12 projects constructed in 2001 and 2002 were sampled, tested and monitored. Laboratory testing involved determining maximum and bulk specific gravities, binder contents, air voids and other properties of the mixes. Laboratory performance tests were also conducted, including Superpave shear tests at high and intermediate temperatures and indirect tensile tests at low temperatures. The Purwheel loaded wheel tester was used to test mixtures from three of the projects to examine the mixes' tendencies to strip and rut.

\section{Findings}

The laboratory testing results generally predicted that all of the mixtures would perform well in the field in terms of rutting. Results ranged from fair to excellent, with the vast majority of the results in the good to excellent categories. The indirect tensile testing results did not indicate any extreme problems would be expected with thermal cracking of these materials. While some of the mixes did have expected critical cracking temperatures warmer than the binder low temperature grade, all of them would be expected to perform well down to about $-17^{\circ} \mathrm{C}$. The single mix with a -28 grade binder, as opposed to the -22 grades for all of the other mixes, also had the lowest critical cracking temperature.

Field performance of these projects was monitored through a condition survey and using videologs, rut depths and roughness measurements from the INDOT Pavement Management System. Through 2009, all 12 projects were performing well with rut depths generally less than 0.1 inch $(2.5 \mathrm{~mm})$ and roughness of less than about $100 \mathrm{in} / \mathrm{mi}$. While there is some cracking on many of the projects, it is generally not severe and is likely reflective rather than thermal cracking.

In general, the laboratory results agree with the field performance. The lab tests suggested that the mixes would be resistant to rutting and fairly resistant to thermal cracking, and this was verified by the field performance in all cases. This study is limited somewhat by the fact that none of the mixes would be expected to perform poorly. Having mixes that "failed" a test would help to establish the boundaries between good and bad performance. The study is also subject to a common limitation of longterm performance studies - the fact that technology has evolved over the course of the project. Mix design parameters have changed somewhat and new test methods, particularly the dynamic modulus and flow number tests, have gained prominence. Nonetheless, this study does show that Superpave mixes from the early part of the century can be expected to perform well and that the laboratory performance tests used in this study generally can predict this good performance. 


\section{Implementation}

The laboratory performance tests, including the Superpave Shear Tester and the Indirect Tensile Tester, in general, showed their ability to predict good performance of the mixtures studied here. Further exploration of the ability of these test methods to identify poor performing mixes is being undertaken in another study, although other research in Indiana and elsewhere shows the applicability of these tests to identify poor performers. Therefore, these test methods may be employed in cases when performance predictions are desired. That other study will also include newly implemented performance tests, including dynamic modulus and flow number tests, to examine their ability to predict performance. Eventually these types of tests could possibly be used to evaluate or predict performance for acceptance testing, failed material evaluations and other cases.

The INDOT Pavement Steering Committee will be made aware of the results of this study for their consideration in future design, specifications and perhaps forensics analysis.

\section{Contacts}

For more information:

\author{
Rebecca McDaniel \\ Principal Investigator \\ Technical Director \\ North Central Superpave Center \\ Purdue University \\ West Lafayette IN 47907 \\ Phone: (765) 463-2317 \\ Fax: (765) 497-2402 \\ E-mail: rsmcdani@purdue.edu
}

Division of Research 1205 Montgomery Street P.O. Box 2279

West Lafayette, IN 47906

Phone: (765) 463-1521

Fax: (765) 497-1665

\section{Purdue University}

Joint Transportation Research Program School of Civil Engineering

West Lafayette, IN 47907-1284

Phone: (765) 494-9310

E:mail: jtrp@ecn.purdue.edu 
Final Report

FHWA/IN/JTRP-2010/21

\title{
PERFORMANCE OF INDIANA'S SUPERPAVE HMA MIXTURES
}

\author{
Ayesha Shah, Research Engineer \\ Rebecca McDaniel (PI), Technical Director \\ North Central Superpave Center \\ Purdue University \\ Joint Transportation Research Program \\ Project Number: \\ File Number: \\ SPR-2417 \\ Conducted in Cooperation with the \\ Indiana Department of Transportation \\ and the \\ Federal Highway Administration
}

The contents of this report reflect the views of the authors, who are responsible for the facts and the accuracy of the data presented herein. The contents do not necessarily reflect the views or policies of the Indiana Department of Transportation and the Federal Highway Administration. This report does not constitute a standard, specification, or regulation.

West Lafayette, IN 47907

April 28, 2011 


\begin{tabular}{|c|c|c|}
\hline $\begin{array}{l}\text { 1. Report No. } \\
\text { FHWA/IN/JTRP-2010/21 }\end{array}$ & 2. Government Accession No. & 3. Recipient's Catalog No. \\
\hline \multirow{2}{*}{\multicolumn{2}{|c|}{$\begin{array}{l}\text { 4. Title and Subtitle } \\
\text { Performance of Indiana's Superpave HMA Mixtures }\end{array}$}} & $\begin{array}{l}\text { 5. Report Date } \\
\text { April } 2011\end{array}$ \\
\hline & & 6. Performing Organization Code \\
\hline \multicolumn{2}{|l|}{$\begin{array}{l}\text { 9. Performing Organization Name and Address } \\
\text { Joint Transportation Research Program } \\
\text { School of Civil Engineering } \\
\text { Purdue University } \\
550 \text { Stadium Mall Drive } \\
\text { West Lafayette, IN 47907-1284 }\end{array}$} & 10. Work Unit No. \\
\hline \multirow{2}{*}{\multicolumn{2}{|c|}{$\begin{array}{l}\text { 12. Sponsoring Agency Name and Address } \\
\text { Indiana Department of Transportation } \\
\text { State Office Building } \\
100 \text { North Senate Avenue } \\
\text { Indianapolis, IN } 46204\end{array}$}} & $\begin{array}{l}\text { 13. Type of Report and Period Covered } \\
\text { Final Report }\end{array}$ \\
\hline & & 14. Sponsoring Agency Code \\
\hline \multicolumn{3}{|l|}{ 15. Supplementary Notes } \\
\hline
\end{tabular}

\section{Abstract}

This project followed the performance of a number of hot mix asphalt paving projects for seven to eight years in an attempt to relate laboratory test results to field performance. First, a small scale study compared sampling locations, specific gravity test procedures and compaction devices used on two samples from projects, one with volumetric acceptance and one with non-volumetric acceptance, to determine the best combination to use for Part 2 of the study. In Part 2, 12 projects constructed in 2001 and 2002 were sampled, tested and monitored. Laboratory testing involved determining maximum and bulk specific gravities, binder content, air voids and other properties of the mixes. Laboratory performance tests were also conducted, including Superpave shear tests at high and intermediate temperatures and indirect tensile tests at low temperatures. The Purwheel loaded wheel tester was used to test mixtures from four of the projects to examine the mixes' tendencies to strip and rut.

The laboratory testing results generally predicted that all of the mixtures would perform well in the field in terms of rutting. Results ranged from fair to excellent, with the vast majority of the results in the good to excellent categories. The indirect tensile testing results did not indicate any extreme problems would be expected with thermal cracking of these materials. While some of the mixes did have expected critical cracking temperatures warmer than the binder low temperature grade, all of them would be expected to perform well down to about $-17^{\circ} \mathrm{C}$. The single mix with a -28 grade binder, as opposed to the -22 grades for all of the other mixes, also had the lowest critical cracking temperature.

Field performance of these projects was monitored through a condition survey and using videologs, rut depths and roughness measurements from the INDOT Pavement Management System. Through 2009, all 12 projects were performing well with rut depths generally less than $0.1 \mathrm{inch}(2.5 \mathrm{~mm})$ and roughness of less than about $100 \mathrm{in} / \mathrm{mi}$. While there is some cracking on many of the projects, it is generally not severe and is likely reflective rather than thermal cracking.

In general then, the laboratory results agree with the field performance. The lab tests suggested that the mixes would be resistant to rutting and fairly resistant to thermal cracking, and this was verified by the field performance in all cases. This study is limited somewhat by the fact that none of the mixes would be expected to perform poorly. Having mixes that "failed" a test would help to establish the boundaries between good and bad performance. The study is also subject to a common limitation of long-term performance studies - the fact that technology has evolved over the course of the project. Mix design parameters have changed somewhat and new test methods, particularly the dynamic modulus and flow number tests, have gained prominence. Nonetheless, this study does show that Superpave mixes from the early part of the century can be expected to perform well and that the laboratory performance tests used in this study generally can predict this good performance.

\section{Key Words}

Asphalt mixtures, pavement performance, permanent deformation, cracking, performance testing

\section{Distribution Statement}

No restrictions. This document is available to the public through the National Technical Information Service, Springfield, VA 22161
19. Security Classif. (of this report)

Unclassified
20. Security Classif. (of this page)

Unclassified
21. No. of Pages

61
22. Price 


\section{TABLE OF CONTENTS}

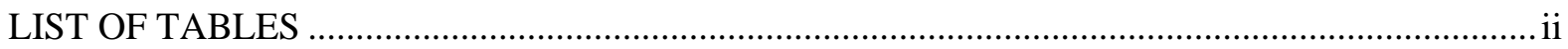

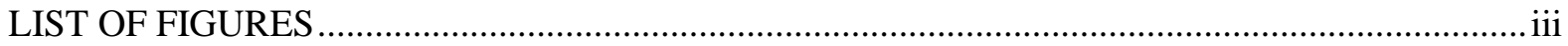

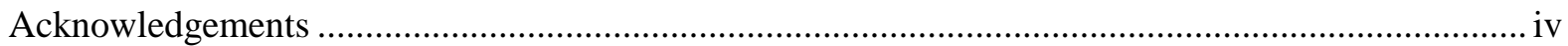

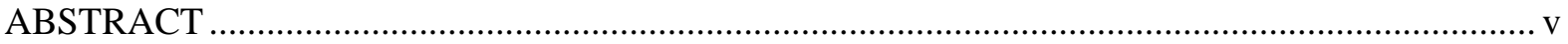

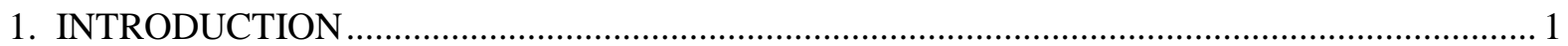

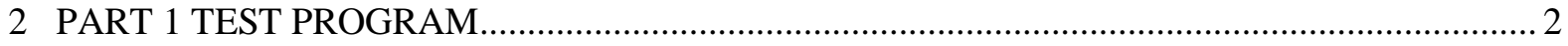

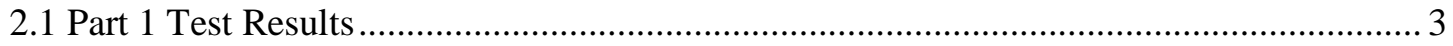

2.1.1 Maximum Theoretical Specific Gravity $\left(\mathrm{G}_{\mathrm{mm}}\right)$......................................... 3

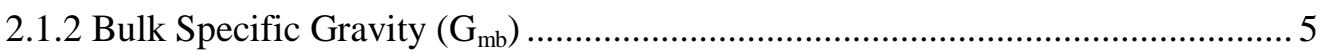

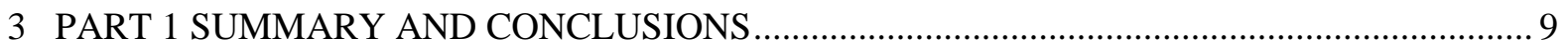

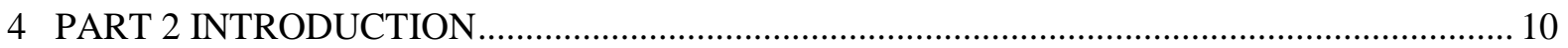

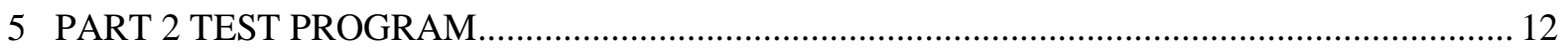

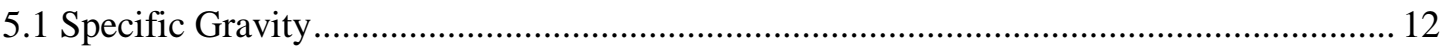

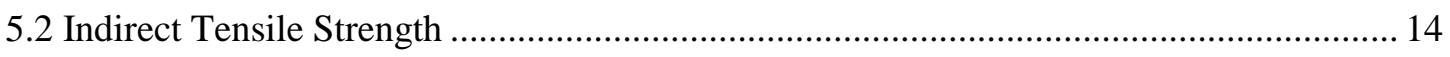

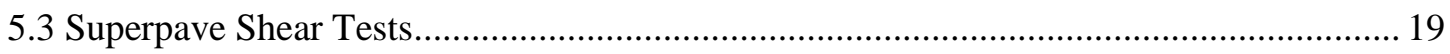

5.3.1 Frequency Sweep at Constant Height........................................................... 19

5.3.2 Simple Shear at Constant Height................................................................ 22

5.3.3 Repeated Shear at Constant Height ............................................................ 24

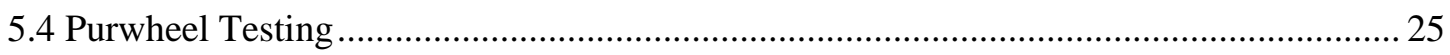

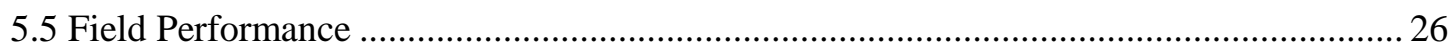

5.5.2 Comparison of Field Performance with Laboratory Test Results .................... 30

6 PART 2 SUMMARY, RECOMMENDATIONS AND CONCLUSIONS .................................. 31

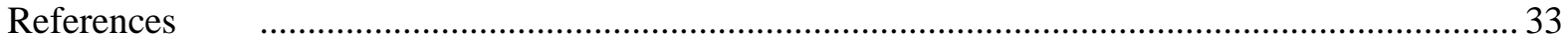

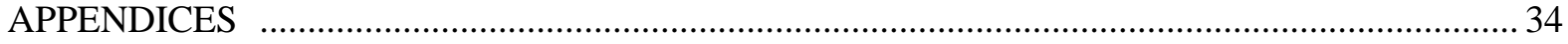

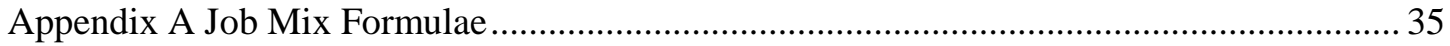

Appendix B Mixture Volumetrics ...................................................................................... 50

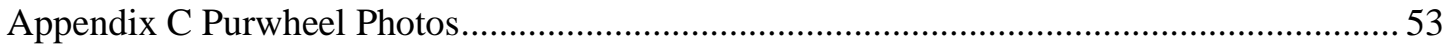




\section{LIST OF TABLES}

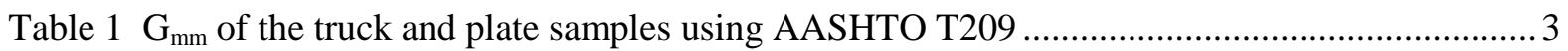

Table $2 \mathrm{G}_{\mathrm{mm}}$ of the truck and plate samples using CoreLok ............................................................... 3

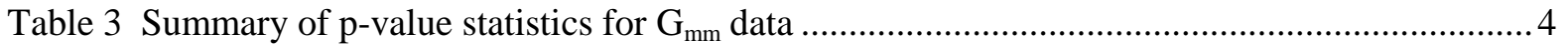

Table $4 \mathrm{G}_{\mathrm{mb}}$ of the truck and plate samples using AASHTO T166 .................................................

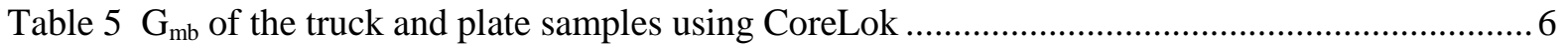

Table 6 Summary of p-value statistics for $\mathrm{G}_{\mathrm{mb}}$ data (Pine compaction) ......................................... 7

Table 7 Summary of p-value statistics for $\mathrm{G}_{\mathrm{mb}}$ data (Troxler compaction) ...................................... 7

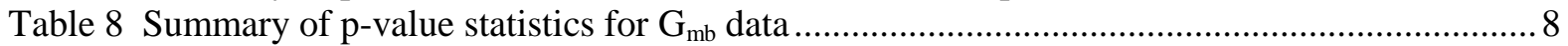

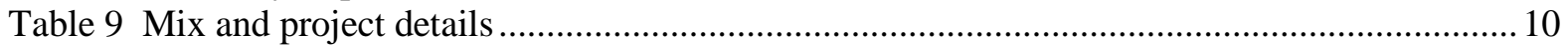

Table 10 Average maximum theoretical specific gravity of the mixes ............................................ 13

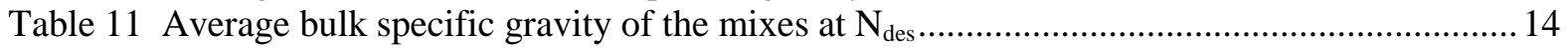

Table 12 Average tensile strengths and stiffnesses of the mixes.................................................. 15

Table 13 Statistical analysis on indirect tensile strength of the mixes ............................................. 17

Table 15 Statistical analysis of IDT strength within each ESAL group .......................................... 18

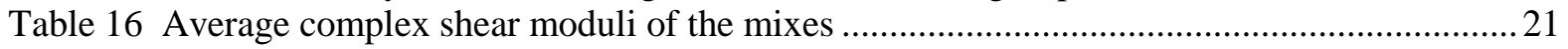

Table 17 Statistical analysis of complex shear moduli of mixes .................................................. 21

Table 18 Statistical analysis of shear moduli based on ESAL classification ....................................22

Table 19 Statistical analysis of shear moduli within each ESAL group ...........................................22

Table 20 Maximum and percent permanent shear strain ..................................................................24

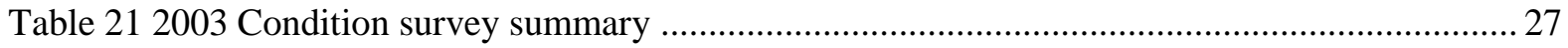

Table 22 Summary of pavement condition data from Pathway videologs ......................................... 28 


\section{LIST OF FIGURES}

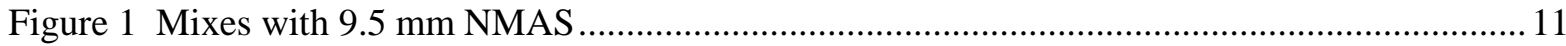

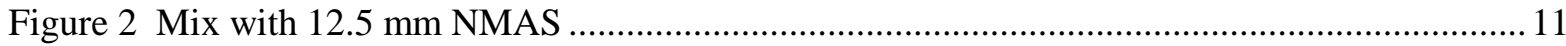

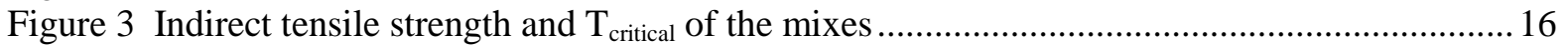

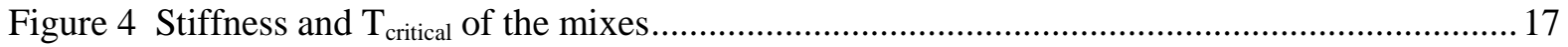

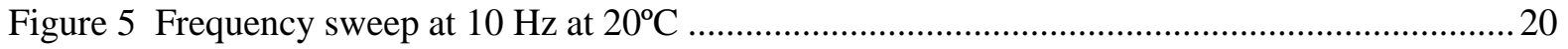

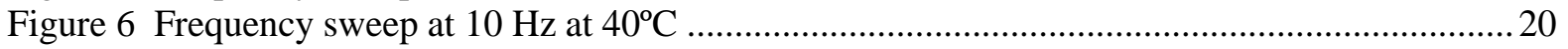

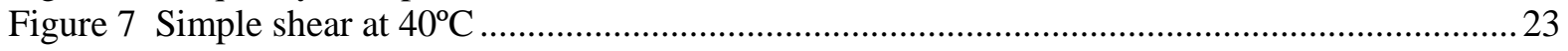

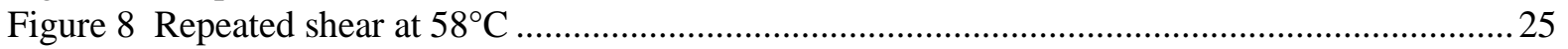




\section{Acknowledgements}

This project was initiated by Dr. Khaled Galal (former Materials Research Engineer, Research Division, INDOT). The work he and the former INDOT lab manager, Kevin Brower, did to further the project along is gratefully acknowledged. Mr. Brower has continued to assist with reconstructing what they did in the early years of the project since leaving INDOT; his help has been invaluable. 


\begin{abstract}
This project followed the performance of a number of hot mix asphalt paving projects for seven to eight years in an attempt to relate laboratory test results to field performance. First, a small scale study compared sampling locations, specific gravity test procedures and compaction devices used on samples from two projects, one with volumetric acceptance and one with non-volumetric acceptance, to determine the best combination to use for Part 2 of the study. In Part 2, 12 projects constructed in 2001 and 2002 were sampled, tested and monitored. Laboratory testing involved determining maximum and bulk specific gravities, binder content, air voids and other properties of the mixes. Laboratory performance tests were also conducted, including Superpave shear tests at high and intermediate temperatures and indirect tensile tests at low temperatures. The Purwheel loaded wheel tester was used to test mixtures from three of the projects to examine the mixes' tendencies to strip and rut.

The laboratory testing results generally predicted that all of the mixtures would perform well in the field in terms of rutting. Results ranged from fair to excellent, with the vast majority of the results in the good to excellent categories. The indirect tensile testing results did not indicate any extreme problems would be expected with thermal cracking of these materials. While some of the mixes did have expected critical cracking temperatures warmer than the binder low temperature grade, all of them would be expected to perform well down to about $-17^{\circ} \mathrm{C}$. The single mix with a -28 grade binder, as opposed to the -22 grades for all of the other mixes, also had the lowest critical cracking temperature.

Field performance of these projects was also monitored through a condition survey and using videologs, rut depths and roughness from the INDOT Pavement Management System. All of the projects are performing acceptably with rut depths generally less than $0.1 \mathrm{inch}(2.5 \mathrm{~mm})$ and roughness of less than $100 \mathrm{in} / \mathrm{mi}$. While there is some cracking on many of the projects, it is generally not severe and is likely reflective rather than thermal cracking.

In general then, the laboratory results agree with the field performance. The lab tests suggested that the mixes would be resistant to rutting and fairly resistant to thermal cracking, and this was verified by the field performance. This study is limited somewhat by the fact that none of the mixes would be expected to perform poorly. Having mixes that "failed" a test would help to establish the boundaries between good and bad performance. The study is also subject to a common limitation of long-term performance studies - the fact that technology has evolved over the course of the project. Mix design parameters have changed somewhat and new test methods, particularly the dynamic modulus and flow number tests, have gained prominence. Nonetheless, this study does show that Superpave mixes from the early part of the century can be expected to perform well and that the laboratory performance tests used in this study generally can predict this good performance.
\end{abstract}




\section{INTRODUCTION}

The original objective of this study was to evaluate the performance of Indiana's Superpave mixes with respect to low temperature cracking and rutting. Plant-produced mixes would be obtained from various projects around the state and subjected to a suite of laboratory tests that would allow the researchers to rank the mixes according to their performance parameters. The concept was to relate mixture volumetrics and quality assurance test results to pavement performance. Ultimately, it was envisioned that this would allow for the establishment of a performance-based tolerance band (PBTB) that would aid the Indiana Department of Transportation (INDOT) and contractors in selecting/developing mixes that may be expected to show good long-term field performance.

The study was conducted in two parts; Part 1 and 2. Since a major portion of this study was to be performed on plant-produced mixes obtained from the job site at the time of construction, it was considered prudent to investigate the differences, if any existed, between plate samples and truck samples. This was due to the concern of some of the Study Advisory Committee (SAC) members, who noted from experience that plate sampling (from the roadway) gave lower variability than truck sampling. However, since obtaining three five-gallon buckets of HMA from plate samples of each project would extensively damage the pavement surface, only two projects were selected for Part 1 of this study. In Part 1, which was to serve as a precursor to the main part of the study (Part 2), only a small subset of the main test program was to be conducted on these mixes, to evaluate differences in specific gravities, asphalt contents, gradations, etc.

It is important to note that Part 1 was intended only to determine if truck sampling was adequately representative of the material on the roadway to fulfill the study objectives. It was not the intent to investigate if plate or truck sampling is preferred for acceptance testing nor to make any policy recommendations regarding sampling.

Part 2 was intended to develop relationships between various mix parameters and field performance. At the time that this project was initiated, the Indiana Department of Transportation (INDOT) was moving into warranty construction, and the contractors were responsible for quality control (QC) testing of their projects to ensure that their mixes satisfied the Superpave volumetric properties. The existing procedures did not include any performance-related tests to assess the longterm in-service performance of the pavement. To fill this gap, researchers at the Division of Research, in collaboration with the North Central Superpave Center (NCSC), proposed conducting Superpave performance tests on typical Superpave mixes used around the state and correlating performance-related parameters with quality assurance (QA) criteria. 
At about the time that this project was getting started, INDOT was piloting a volumetric acceptance program, which it eventually adopted. Under this program, INDOT accepts asphalt mixtures on the basis of binder content, voids in the mineral aggregate (VMA) at $\mathrm{N}_{\text {design }}$ and air voids at $\mathrm{N}_{\text {design. }}$ Prior to the adoption of volumetric acceptance, mixes were accepted based on gradation, binder content and coarse aggregate angularity. In this study, both volumetric and non-volumetric projects were sampled and tested in Part 1 and volumetric projects only were sampled in Part 2. A total of eight different contractors produced the mixes tested in this study, including two in Part 1 sampled in 2000, the two from Part 1 plus five additional contractors in 2001 and a total of three, including one additional contractor, in 2002. Projects were located in five of the six districts in the state.

\section{PART 1 TEST PROGRAM}

Two projects under construction in August 2000 were selected for Part 1 of this study. Both mixes had a nominal maximum aggregate size (NMAS) of $9.5 \mathrm{~mm}$ and the same binder grade (PG7622). One project was on US31 in the Greenfield district, while the other was on US30 in the LaPorte district. Both mixes were Superpave designed mixes, but the US31 project was a volumetric acceptance project, whereas the US30 contract was non-volumetric acceptance. The job mix formulae for the two mixes are shown in Appendix A.

The mix samples obtained from the field were sent to the INDOT Research Division for lab testing. The mixes were heated at $165^{\circ} \mathrm{C}\left(275^{\circ} \mathrm{F}\right)$ for approximately four hours and then split into smaller sample sizes by the quartering method. The tests conducted on these mixes included:

- Pine and Troxler gyratory compaction (AASHTO T312)

- Bulk specific gravity determination (AASHTO T166 and T331)

- Maximum theoretical specific gravity determination (AASHTO T209)

- Asphalt extraction (AASHTO T164)

- Gradation of extracted aggregate (ASTM D 5444)

In addition to investigating the differences between samples obtained from plate and truck sampling, differences between some test procedures and devices were also investigated, i.e., the differences between (a) the traditional AASHTO methods (T166 and T209) and the vacuum-sealing method (CoreLok) and (b) compaction in Pine and Troxler gyratory compactors. (Results from the extraction and gradation testing of these two mixes are summarized in Appendix B.) 


\subsection{Part 1 Test Results}

\subsubsection{Maximum Theoretical Specific Gravity $\left(G_{m m}\right)$}

Three replicate samples were prepared for each mix in accordance with AASHTO T209 after the five-gallon bucket samples were quartered and split into smaller sizes. Determination of the maximum theoretical specific gravity of the mixes was conducted using both the Rice test method (AASHTO T209) and the vacuum-sealing method (ASTM D 6857). Tables 1 and 2 show the averages and coefficients of variation of the $G_{\mathrm{mm}}$ for the truck and plate samples, using the conventional and the vacuum-sealing methods, respectively. Low coefficients of variation were observed in the test results indicating good repeatability.

Table $1 \mathrm{G}_{\mathrm{mm}}$ of the truck and plate samples using AASHTO T209

\begin{tabular}{|c|c|c|c|c|c|}
\hline Site ID & Sample & Replicate \# & $\mathbf{G}_{\mathrm{mm}}$ & Average & C. V., \% \\
\hline \multirow{3}{*}{ US30 } & \multirow{3}{*}{ Truck } & 1 & 2.491 & \multirow{3}{*}{2.488} & \multirow{3}{*}{0.21} \\
\hline & & 2 & 2.491 & & \\
\hline & & 3 & 2.481 & & \\
\hline \multirow{3}{*}{ US31 } & \multirow{3}{*}{ Truck } & 1 & 2.474 & \multirow{3}{*}{2.478} & \multirow{3}{*}{0.31} \\
\hline & & 2 & 2.487 & & \\
\hline & & 3 & 2.474 & & \\
\hline \multirow{3}{*}{ US30 } & \multirow{3}{*}{ Plate } & 1 & 2.477 & \multirow{3}{*}{2.473} & \multirow{3}{*}{0.21} \\
\hline & & 2 & 2.467 & & \\
\hline & & 3 & 2.475 & & \\
\hline \multirow{3}{*}{ US31 } & \multirow{3}{*}{ Plate } & 1 & 2.450 & \multirow{3}{*}{2.456} & \multirow{3}{*}{0.32} \\
\hline & & 2 & 2.453 & & \\
\hline & & 3 & 2.465 & & \\
\hline
\end{tabular}

Table $2 \mathrm{G}_{\mathrm{mm}}$ of the truck and plate samples using CoreLok

\begin{tabular}{|c|c|c|c|c|c|}
\hline Site ID & Sample & Replicate \# & $\mathbf{G}_{\mathrm{mm}}$ & Average & C. V., \% \\
\hline \multirow{3}{*}{ US30 } & \multirow{3}{*}{ Truck } & 1 & 2.473 & \multirow{3}{*}{2.473} & \multirow{3}{*}{0.05} \\
\hline & & 2 & 2.474 & & \\
\hline & & 3 & 2.472 & & \\
\hline \multirow{3}{*}{ US31 } & \multirow{3}{*}{ Truck } & 1 & 2.434 & \multirow{3}{*}{2.464} & \multirow{3}{*}{1.07} \\
\hline & & 2 & 2.483 & & \\
\hline & & 3 & 2.476 & & \\
\hline \multirow{3}{*}{ US30 } & \multirow{3}{*}{ Plate } & 1 & 2.481 & \multirow{3}{*}{2.486} & \multirow{3}{*}{0.24} \\
\hline & & 2 & 2.485 & & \\
\hline & & 3 & 2.493 & & \\
\hline \multirow{3}{*}{ US31 } & \multirow{3}{*}{ Plate } & 1 & 2.453 & \multirow{3}{*}{2.470} & \multirow{3}{*}{0.62} \\
\hline & & 2 & 2.478 & & \\
\hline & & 3 & 2.480 & & \\
\hline
\end{tabular}


Single factor analysis of variance (ANOVA) was conducted on the data from each mix to test for differences in the mean $(\mu) G_{m m}$ of the mixes. The ANOVA analysis was conducted to evaluate the impact of (a) sampling location (truck vs. plate) and (b) test method (Rice vs. CoreLok). The null hypothesis was that the means were equal. The significance level, $\alpha$, chosen for analysis was 0.05 . If the p-value obtained from ANOVA was $\leq 0.05$, it could be inferred that the null hypothesis was false, i.e. that the samples were significantly different. Table 3 shows the summary of the ANOVA conducted on the $\mathrm{G}_{\mathrm{mm}}$ data.

Table 3 Summary of p-value statistics for $\mathrm{G}_{\mathrm{mm}}$ data

\begin{tabular}{|c|c|l|c|c|}
\hline Fixed factors & Variable & Hypothesis & p-value & Conclusion \\
\hline $\begin{array}{c}\text { US30 } \\
\text { AASHTO T166 }\end{array}$ & $\begin{array}{c}\text { truck vs. } \\
\text { plate }\end{array}$ & $\mu_{\mathrm{TRK}}=\mu_{\mathrm{PLT}}$ & 0.0301 & $\begin{array}{c}\text { Significantly } \\
\text { different }\end{array}$ \\
\hline $\begin{array}{c}\text { US30 } \\
\text { AASHTO T331 }\end{array}$ & $\begin{array}{c}\text { truck vs. } \\
\text { plate }\end{array}$ & $\mu_{\mathrm{TRK}}=\mu_{\mathrm{PLT}}$ & 0.1364 & $\begin{array}{c}\text { No significant } \\
\text { differences }\end{array}$ \\
\hline $\begin{array}{c}\text { US31 } \\
\text { AASHTO T166 }\end{array}$ & $\begin{array}{c}\text { truck vs. } \\
\text { plate }\end{array}$ & $\mu_{\mathrm{TRK}}=\mu_{\mathrm{PLT}}$ & 0.0233 & $\begin{array}{c}\text { Significantly } \\
\text { different }\end{array}$ \\
\hline $\begin{array}{c}\text { US31 } \\
\text { AASHTO T331 }\end{array}$ & $\begin{array}{c}\text { truck vs. } \\
\text { plate }\end{array}$ & $\mu_{\mathrm{TRK}}=\mu_{\mathrm{PLT}}$ & 0.7960 & $\begin{array}{c}\text { No significant } \\
\text { differences }\end{array}$ \\
\hline $\begin{array}{c}\text { US30 } \\
\text { Plate sample }\end{array}$ & $\begin{array}{c}\text { Rice vs. } \\
\text { CoreLok }\end{array}$ & $\mu_{\mathrm{RCE}}=\mu_{\mathrm{CLK}}$ & 0.8945 & $\begin{array}{c}\text { No significant } \\
\text { differences }\end{array}$ \\
\hline $\begin{array}{c}\text { US30 } \\
\text { Truck sample }\end{array}$ & $\begin{array}{c}\text { Rice vs. } \\
\text { CoreLok }\end{array}$ & $\mu_{\mathrm{RCE}}=\mu_{\mathrm{CLK}}$ & 0.0040 & $\begin{array}{c}\text { Significantly } \\
\text { different }\end{array}$ \\
\hline $\begin{array}{c}\text { US31 } \\
\text { Plate sample }\end{array}$ & $\begin{array}{c}\text { Rice vs. } \\
\text { CoreLok }\end{array}$ & $\mu_{\mathrm{RCE}}=\mu_{\mathrm{CLK}}$ & 0.2301 & $\begin{array}{c}\text { No significant } \\
\text { differences }\end{array}$ \\
\hline $\begin{array}{c}\text { US31 } \\
\text { Truck sample }\end{array}$ & $\begin{array}{c}\text { Rice vs. } \\
\text { CoreLok }\end{array}$ & $\mu_{\mathrm{RCE}}=\mu_{\mathrm{CLK}}$ & 0.4304 & $\begin{array}{c}\text { No significant } \\
\text { differences }\end{array}$ \\
\hline
\end{tabular}

These results indicate that no statistically significant differences between plate (PLT) and truck (TRK) samples were observed in the mean $\mathrm{G}_{\mathrm{mm}}$ of the two mixes when the CoreLok method (CLK) was used. However, when the traditional Rice method (RCE) was used, significant differences were found between plate and truck samples for both projects.

Plate samples did not show any significant differences when tested by the Rice and the CoreLok methods, for either mix. However, the truck sample data indicated that the average $\mathrm{G}_{\mathrm{mm}}$ values determined using the two methods were statistically different for US30, but not for US31. A duplicate set of results was obtained by preparing additional replicate samples of the US30 mix. This duplicate set of results also supported the earlier conclusion that the average $G_{m m}$ values obtained using the two test methods were statistically different for this mix. 


\subsubsection{Bulk Specific Gravity $\left(G_{m b}\right)$}

Three replicate samples were prepared and compacted for each mix in accordance with AASHTO T312 and tested in accordance with AASHTO T116 and AASHTO T331. These results are presented in Tables 4 and 5, respectively. The coefficients of variation were low for both test methods; ranging from 0.05 to 0.41 for the traditional method and from 0.05 to 0.46 for the CoreLok method. In addition, mix samples from both the plate and the truck samples were compacted using the Pine and the Troxler gyratory compactors. The variability, as measured by the coefficient of variation, was low in both cases; 0.05 to 0.42 for Pine and 0.15 to 0.46 for Troxler compacted pills.

Table $4 \mathrm{G}_{\mathrm{mb}}$ of the truck and plate samples using AASHTO T166

\begin{tabular}{|c|c|c|c|c|c|c|}
\hline Site ID & Sample & Compactor & Replicate \# & $\mathbf{G}_{\mathbf{m m}}$ & Average & C. V., \% \\
\hline \multirow{6}{*}{ US30 } & \multirow{6}{*}{ Truck } & \multirow{3}{*}{ Pine } & 1 & 2.382 & \multirow{3}{*}{2.382} & \multirow{3}{*}{0.05} \\
\hline & & & 2 & 2.381 & & \\
\hline & & & 3 & 2.384 & & \\
\hline & & \multirow{3}{*}{ Troxler } & 1 & 2.359 & \multirow{3}{*}{2.366} & \multirow{3}{*}{0.41} \\
\hline & & & 2 & 2.377 & & \\
\hline & & & 3 & 2.361 & & \\
\hline \multirow{6}{*}{ US31 } & \multirow{6}{*}{ Truck } & \multirow{3}{*}{ Pine } & 1 & 2.384 & \multirow{3}{*}{2.378} & \multirow{3}{*}{0.25} \\
\hline & & & 2 & 2.372 & & \\
\hline & & & 3 & 2.379 & & \\
\hline & & \multirow{3}{*}{ Troxler } & 1 & 2.375 & \multirow{3}{*}{2.366} & \multirow{3}{*}{0.41} \\
\hline & & & 2 & 2.356 & & \\
\hline & & & 3 & 2.365 & & \\
\hline \multirow{6}{*}{ US30 } & \multirow{6}{*}{ Plate } & \multirow{3}{*}{ Pine } & 1 & 2.388 & \multirow{3}{*}{2.390} & \multirow{3}{*}{0.19} \\
\hline & & & 2 & 2.395 & & \\
\hline & & & 3 & 2.387 & & \\
\hline & & \multirow{3}{*}{ Troxler } & 1 & 2.376 & \multirow{3}{*}{2.374} & \multirow{3}{*}{0.15} \\
\hline & & & 2 & 2.369 & & \\
\hline & & & 3 & 2.375 & & \\
\hline \multirow{6}{*}{ US31 } & \multirow{6}{*}{ Plate } & \multirow{3}{*}{ Pine } & 1 & 2.396 & \multirow{3}{*}{2.397} & \multirow{3}{*}{0.13} \\
\hline & & & 2 & 2.400 & & \\
\hline & & & 3 & 2.394 & & \\
\hline & & \multirow{3}{*}{ Troxler } & 1 & 2.394 & \multirow{3}{*}{2.388} & \multirow{3}{*}{0.27} \\
\hline & & & 2 & 2.390 & & \\
\hline & & & 3 & 2.381 & & \\
\hline
\end{tabular}


Table $5 \mathrm{G}_{\mathrm{mb}}$ of the truck and plate samples using CoreLok

\begin{tabular}{|c|c|c|c|c|c|c|}
\hline Site ID & Sample & Compactor & Replicate \# & $\mathbf{G}_{\mathbf{m m}}$ & Average & C. V., \% \\
\hline \multirow{6}{*}{ US30 } & \multirow{6}{*}{ Truck } & \multirow{3}{*}{ Pine } & 1 & 2.381 & \multirow{3}{*}{2.380} & \multirow{3}{*}{0.05} \\
\hline & & & 2 & 2.379 & & \\
\hline & & & 3 & 2.381 & & \\
\hline & & \multirow{3}{*}{ Troxler } & 1 & 2.351 & \multirow{3}{*}{2.360} & \multirow{3}{*}{0.51} \\
\hline & & & 2 & 2.374 & & \\
\hline & & & 3 & 2.355 & & \\
\hline \multirow{6}{*}{ US31 } & \multirow{6}{*}{ Truck } & \multirow{3}{*}{ Pine } & 1 & 2.370 & \multirow{3}{*}{2.367} & \multirow{3}{*}{0.18} \\
\hline & & & 2 & 2.362 & & \\
\hline & & & 3 & 2.368 & & \\
\hline & & \multirow{3}{*}{ Troxler } & 1 & 2.368 & \multirow{3}{*}{2.357} & \multirow{3}{*}{0.46} \\
\hline & & & 2 & 2.346 & & \\
\hline & & & 3 & 2.357 & & \\
\hline \multirow{6}{*}{ US30 } & \multirow{6}{*}{ Plate } & \multirow{3}{*}{ Pine } & 1 & 2.396 & \multirow{3}{*}{2.394} & \multirow{3}{*}{0.42} \\
\hline & & & 2 & 2.403 & & \\
\hline & & & 3 & 2.384 & & \\
\hline & & \multirow{3}{*}{ Troxler } & 1 & 2.361 & \multirow{3}{*}{2.367} & \multirow{3}{*}{0.21} \\
\hline & & & 2 & 2.368 & & \\
\hline & & & 3 & 2.371 & & \\
\hline \multirow{6}{*}{ US31 } & \multirow{6}{*}{ Plate } & \multirow{3}{*}{ Pine } & 1 & 2.389 & \multirow{3}{*}{2.387} & \multirow{3}{*}{0.17} \\
\hline & & & 2 & 2.388 & & \\
\hline & & & 3 & 2.382 & & \\
\hline & & \multirow{3}{*}{ Troxler } & 1 & 2.384 & \multirow{3}{*}{2.378} & \multirow{3}{*}{0.30} \\
\hline & & & 2 & 2.379 & & \\
\hline & & & 3 & 2.370 & & \\
\hline
\end{tabular}

Statistical analysis was conducted on these data sets to test for differences in the mean $G_{m b}$ obtained from (i) plate versus truck samples (ii) Rice versus CoreLok method and (iii) Pine versus Troxler samples. The p-values from these analyses are presented in Tables 6, 7 and 8. 
Table 6 Summary of p-value statistics for $\mathrm{G}_{\mathrm{mb}}$ data (Pine compaction)

\begin{tabular}{|c|c|c|c|c|}
\hline Fixed factors & Variable & Hypothesis & p-value & Conclusion \\
\hline $\begin{array}{c}\text { US30 } \\
\text { AASHTO T166 }\end{array}$ & $\begin{array}{l}\text { truck vs. } \\
\text { plate }\end{array}$ & $\mu_{\mathrm{TRK}}=\mu_{\mathrm{PLT}}$ & 0.0448 & $\begin{array}{c}\text { Significantly } \\
\text { different }\end{array}$ \\
\hline $\begin{array}{c}\text { US30 } \\
\text { AASHTO T331 }\end{array}$ & $\begin{array}{l}\text { truck vs. } \\
\text { plate }\end{array}$ & $\mu_{\mathrm{TRK}}=\mu_{\mathrm{PLT}}$ & 0.0752 & $\begin{array}{c}\text { No significant } \\
\text { differences }\end{array}$ \\
\hline $\begin{array}{c}\text { US31 } \\
\text { AASHTO T166 }\end{array}$ & $\begin{array}{l}\text { truck vs. } \\
\text { plate }\end{array}$ & $\mu_{\mathrm{TRK}}=\mu_{\mathrm{PLT}}$ & 0.0081 & $\begin{array}{c}\text { Significantly } \\
\text { different }\end{array}$ \\
\hline $\begin{array}{c}\text { US31 } \\
\text { AASHTO T331 }\end{array}$ & $\begin{array}{l}\text { truck vs. } \\
\text { plate }\end{array}$ & $\mu_{\mathrm{TRK}}=\mu_{\mathrm{PLT}}$ & 0.0041 & $\begin{array}{c}\text { Significantly } \\
\text { different }\end{array}$ \\
\hline $\begin{array}{c}\text { US30 } \\
\text { Plate sample }\end{array}$ & $\begin{array}{l}\text { Rice vs. } \\
\text { CoreLok }\end{array}$ & $\mu_{\mathrm{RCE}}=\mu_{\mathrm{CLK}}$ & 0.5457 & $\begin{array}{c}\text { No significant } \\
\text { differences }\end{array}$ \\
\hline $\begin{array}{c}\text { US30 } \\
\text { Truck sample }\end{array}$ & $\begin{array}{l}\text { Rice vs. } \\
\text { CoreLok }\end{array}$ & $\mu_{\mathrm{RCE}}=\mu_{\mathrm{CLK}}$ & 0.1101 & $\begin{array}{c}\text { No significant } \\
\text { differences }\end{array}$ \\
\hline $\begin{array}{c}\text { US31 } \\
\text { Plate sample }\end{array}$ & $\begin{array}{l}\text { Rice vs. } \\
\text { CoreLok }\end{array}$ & $\mu_{\mathrm{RCE}}=\mu_{\mathrm{CLK}}$ & 0.0261 & $\begin{array}{c}\text { Significantly } \\
\text { different }\end{array}$ \\
\hline $\begin{array}{c}\text { US31 } \\
\text { Truck sample }\end{array}$ & $\begin{array}{l}\text { Rice vs. } \\
\text { CoreLok }\end{array}$ & $\mu_{\mathrm{RCE}}=\mu_{\mathrm{CLK}}$ & 0.0524 & $\begin{array}{c}\text { No significant } \\
\text { differences }\end{array}$ \\
\hline
\end{tabular}

Table 7 Summary of p-value statistics for $\mathrm{G}_{\mathrm{mb}}$ data (Troxler compaction)

\begin{tabular}{|c|c|c|c|c|}
\hline Fixed factors & Variable & Hypothesis & p-value & Conclusion \\
\hline $\begin{array}{c}\text { US30 } \\
\text { AASHTO T166 }\end{array}$ & $\begin{array}{l}\text { truck vs. } \\
\text { plate }\end{array}$ & $\mu_{\mathrm{TRK}}=\mu_{\mathrm{PLT}}$ & 0.2602 & $\begin{array}{l}\text { No significant } \\
\text { differences }\end{array}$ \\
\hline $\begin{array}{c}\text { US30 } \\
\text { AASHTO T331 }\end{array}$ & $\begin{array}{l}\text { truck vs. } \\
\text { plate }\end{array}$ & $\mu_{\mathrm{TRK}}=\mu_{\mathrm{PLT}}$ & 0.4403 & $\begin{array}{l}\text { No significant } \\
\text { differences }\end{array}$ \\
\hline $\begin{array}{c}\text { US31 } \\
\text { AASHTO T166 }\end{array}$ & $\begin{array}{l}\text { truck vs. } \\
\text { plate }\end{array}$ & $\mu_{\mathrm{TRK}}=\mu_{\mathrm{PLT}}$ & 0.0274 & $\begin{array}{c}\text { Significantly } \\
\text { different }\end{array}$ \\
\hline $\begin{array}{c}\text { US31 } \\
\text { AASHTO T331 }\end{array}$ & $\begin{array}{l}\text { truck vs. } \\
\text { plate }\end{array}$ & $\mu_{\mathrm{TRK}}=\mu_{\mathrm{PLT}}$ & 0.0517 & $\begin{array}{c}\text { No significant } \\
\text { differences }\end{array}$ \\
\hline $\begin{array}{c}\text { US30 } \\
\text { Plate sample }\end{array}$ & $\begin{array}{l}\text { Rice vs. } \\
\text { CoreLok }\end{array}$ & $\mu_{\mathrm{RCE}}=\mu_{\mathrm{CLK}}$ & 0.1239 & $\begin{array}{l}\text { No significant } \\
\text { differences }\end{array}$ \\
\hline $\begin{array}{c}\text { US30 } \\
\text { Truck sample }\end{array}$ & $\begin{array}{l}\text { Rice vs. } \\
\text { CoreLok }\end{array}$ & $\mu_{\mathrm{RCE}}=\mu_{\mathrm{CLK}}$ & 0.5762 & $\begin{array}{l}\text { No significant } \\
\text { differences }\end{array}$ \\
\hline $\begin{array}{c}\text { US31 } \\
\text { Plate sample }\end{array}$ & $\begin{array}{l}\text { Rice vs. } \\
\text { CoreLok }\end{array}$ & $\mu_{\mathrm{RCE}}=\mu_{\mathrm{CLK}}$ & 0.1275 & $\begin{array}{l}\text { No significant } \\
\text { differences }\end{array}$ \\
\hline $\begin{array}{c}\text { US31 } \\
\text { Truck sample }\end{array}$ & $\begin{array}{l}\text { Rice vs. } \\
\text { CoreLok }\end{array}$ & $\mu_{\mathrm{RCE}}=\mu_{\mathrm{CLK}}$ & 0.3697 & $\begin{array}{l}\text { No significant } \\
\text { differences }\end{array}$ \\
\hline
\end{tabular}

Pine compacted samples: Bulk specific gravities of the Pine compacted samples determined using the traditional method showed significant differences in the mean $\mathrm{G}_{\mathrm{mb}}$ of truck versus plate samples; however, when they were tested using the CoreLok only the US31 samples showed differences, but 
not the US30 samples. No significant differences were found in the mean $\mathrm{G}_{\mathrm{mb}}$ of CoreLok versus traditional methods from truck samples compacted using the Pine gyratory compactor. In the case of plate samples, however, the US31 samples were found to be different, but not the US30 samples.

Troxler compacted samples: No significant differences in the mean $\mathrm{G}_{\mathrm{mb}}$ of plate versus truck samples, compacted using the Troxler gyratory compactor, were found using the CoreLok method. When the traditional method was used, no statistical differences were found between the plate and truck sample from US30 only, but the US31 results were significantly different. The mean $\mathrm{G}_{\mathrm{mb}}$ of Troxler-compacted plate samples showed no statistical differences between the CoreLok method and the traditional method, for both mixes. The same was true in the case of the truck samples.

Table 8 Summary of p-value statistics for $\mathrm{G}_{\mathrm{mb}}$ data

\begin{tabular}{|c|c|c|c|c|}
\hline Fixed factors & Variable & Hypothesis & p-value & Conclusion \\
\hline $\begin{array}{c}\text { AASHTO T166 } \\
\text { Plate sample }\end{array}$ & $\begin{array}{c}\text { Pine vs. } \\
\text { Troxler }\end{array}$ & $\mu_{\mathrm{PIN}}=\mu_{\mathrm{TRX}}$ & 0.0076 & $\begin{array}{c}\text { Significantly } \\
\text { different }\end{array}$ \\
\hline $\begin{array}{c}\text { US30 } \\
\text { AASHTO T331 } \\
\text { Plate sample }\end{array}$ & $\begin{array}{c}\text { Pine vs. } \\
\text { Troxler }\end{array}$ & $\mu_{\mathrm{PIN}}=\mu_{\mathrm{TRX}}$ & 0.0126 & $\begin{array}{c}\text { Significantly } \\
\text { different }\end{array}$ \\
\hline $\begin{array}{c}\text { US31 } \\
\text { AASHTO T166 } \\
\text { Plate sample }\end{array}$ & $\begin{array}{c}\text { Pine vs. } \\
\text { Troxler }\end{array}$ & $\mu_{\mathrm{PIN}}=\mu_{\mathrm{TRX}}$ & 0.1150 & $\begin{array}{c}\text { No significant } \\
\text { differences }\end{array}$ \\
\hline $\begin{array}{c}\text { US31 } \\
\text { AASHTO T331 } \\
\text { Plate sample }\end{array}$ & $\begin{array}{c}\text { Pine vs. } \\
\text { Troxler }\end{array}$ & $\mu_{\mathrm{PIN}}=\mu_{\mathrm{TRX}}$ & 0.1344 & $\begin{array}{c}\text { No significant } \\
\text { differences }\end{array}$ \\
\hline $\begin{array}{c}\text { US30 } \\
\text { AASHTO T166 } \\
\text { Truck sample }\end{array}$ & $\begin{array}{c}\text { Pine vs. } \\
\text { Troxler }\end{array}$ & $\mu_{\mathrm{PIN}}=\mu_{\mathrm{TRX}}$ & 0.0419 & $\begin{array}{c}\text { Significantly } \\
\text { different }\end{array}$ \\
\hline $\begin{array}{c}\text { US30 } \\
\text { AASHTO T331 } \\
\text { Truck sample }\end{array}$ & $\begin{array}{c}\text { Pine vs. } \\
\text { Troxler }\end{array}$ & $\mu_{\mathrm{PIN}}=\mu_{\mathrm{TRX}}$ & 0.0438 & $\begin{array}{c}\text { Significantly } \\
\text { different }\end{array}$ \\
\hline $\begin{array}{c}\text { US31 } \\
\text { AASHTO T166 } \\
\text { Truck sample }\end{array}$ & $\begin{array}{c}\text { Pine vs. } \\
\text { Troxler }\end{array}$ & $\mu_{\mathrm{PIN}}=\mu_{\mathrm{TRX}}$ & 0.1293 & $\begin{array}{c}\text { No significant } \\
\text { differences }\end{array}$ \\
\hline $\begin{array}{c}\text { US31 } \\
\text { AASHTO T331 } \\
\text { Truck sample }\end{array}$ & $\begin{array}{c}\text { Pine vs. } \\
\text { Troxler }\end{array}$ & $\mu_{\mathrm{PIN}}=\mu_{\mathrm{TRX}}$ & 0.2288 & $\begin{array}{c}\text { No significant } \\
\text { differences }\end{array}$ \\
\hline
\end{tabular}

Troxler versus Pine compactions: Comparison of $\mathrm{G}_{\mathrm{mb}}$ data of Pine versus Troxler compacted samples showed no statistically significant differences between the two compactors when tested using either the CoreLok method or the traditional method for the US31 truck and plate mixes. However, in the case of the US30 truck and plate mixes, significant differences were found between the two compactors tested using either the CoreLok or the traditional method. 


\section{PART 1 SUMMARY AND CONCLUSIONS}

In general, statistical analyses of the $G_{m m}$ data indicated that there were no statistical differences between the mean $G_{m m}$ values of plate and truck samples when determined using the CoreLok method. There were significant differences between the plate and truck samples when tested by the Rice method. The Rice and Corelok results were significantly different for the truck samples from US30 but not from the other samples.

In most cases, analyses of the $\mathrm{G}_{\mathrm{mb}}$ data indicated no statistically significant differences between the two test methods for Pine and Troxler compacted samples fabricated using either plate or truck samples. Both the CoreLok and traditional methods indicated no significant differences between the $\mathrm{G}_{\mathrm{mb}}$ of plate and truck samples compacted using the Troxler machine. However, Pine compacted samples showed statistical differences between the plate and the truck samples in some cases, especially when the Rice method was used.

As a result of these observations, it was decided that mixes obtained by truck sampling (easier to obtain than plate samples) would be used for Part 2 of this study. (The SAC agreed plate sampling was not feasible or necessary but actually recommended that samples be collected from a diverter chute or front end loader at the plant. These were not readily available at most of the plants sampled so truck sampling was used.) Further, the Pine Gyratory Compactor would be used for producing the pills necessary for testing; this decision was made because the Pine gyratory belonged to INDOT (the Troxler belonged to the NCSC) and the INDOT researcher preferred using the compactor with which he was more familiar. Both the Corelok and the traditional AASHTO T166 methods would be used to determine the maximum and the bulk specific gravity of the samples in Part 2 to allow for developing more experience with the relatively new Corelok method. 


\section{PART 2 INTRODUCTION}

In Part 2, hot-mix samples (truck samples) from various job sites around the state of Indiana were collected in five-gallon buckets at the time of construction. Nine projects were sampled in 2001 and three in 2002. (A tenth project had been sampled in 2001 and tested, however, discrepancies in the records regarding the location and contract number were later found. Because these discrepancies could not be resolved, the project was dropped from the study.) The projects were distributed over five of the six districts in the state. All of these projects were volumetric acceptance projects.

The samples were sent to the laboratory at the Division of Research of the Indiana Department of Transportation and stored at room temperature until further testing. Of the 12 mixture samples studied, 11 samples were $9.5 \mathrm{~mm}$ NMAS mixes and one was a $12.5 \mathrm{~mm}$ mix. The binder grades and design ESALs for these mixes are shown in Table 9, and the aggregate gradations are shown in Figures 1 and 2. The designs (DMFs) for these mixes are shown in Appendix A along with the values of some mixture properties measured in the Division of Research laboratory.

Table 9 Mix and project details

\begin{tabular}{|c|c|c|c|c|c|}
\hline Site ID & Binder & NMAS & $\mathbf{N}_{\text {des }}$ & $\begin{array}{c}\text { ESALs } \\
\text { (millions) }\end{array}$ & Year \\
\hline SR37 & PG64-22 & $9.5 \mathrm{~mm}$ & 75 & 1.5 & 2001 \\
\hline US40 & PG64-22 & $12.5 \mathrm{~mm}$ & 100 & $3-30$ & 2002 \\
\hline US231 & PG70-22 & $9.5 \mathrm{~mm}$ & 75 & 2.5 & 2001 \\
\hline US50 & PG70-22 & $9.5 \mathrm{~mm}$ & 75 & 2.5 & 2001 \\
\hline SR66 & PG70-22 & $9.5 \mathrm{~mm}$ & 100 & 6.8 & 2002 \\
\hline US31k & PG70-22 & $9.5 \mathrm{~mm}$ & 100 & 11 & 2001 \\
\hline US31i & PG70-22 & $9.5 \mathrm{~mm}$ & 100 & 20 & 2001 \\
\hline SR135 & PG70-22 & $9.5 \mathrm{~mm}$ & 100 & 20 & 2002 \\
\hline SR49 & PG70-28 & $9.5 \mathrm{~mm}$ & 100 & 22 & 2001 \\
\hline US24 & PG76-22 & $9.5 \mathrm{~mm}$ & 100 & 5.6 & 2001 \\
\hline SR32 & PG76-22 & $9.5 \mathrm{~mm}$ & 100 & 8 & 2001 \\
\hline SR930 & PG76-22 & $9.5 \mathrm{~mm}$ & 125 & 35 & 2001 \\
\hline
\end{tabular}




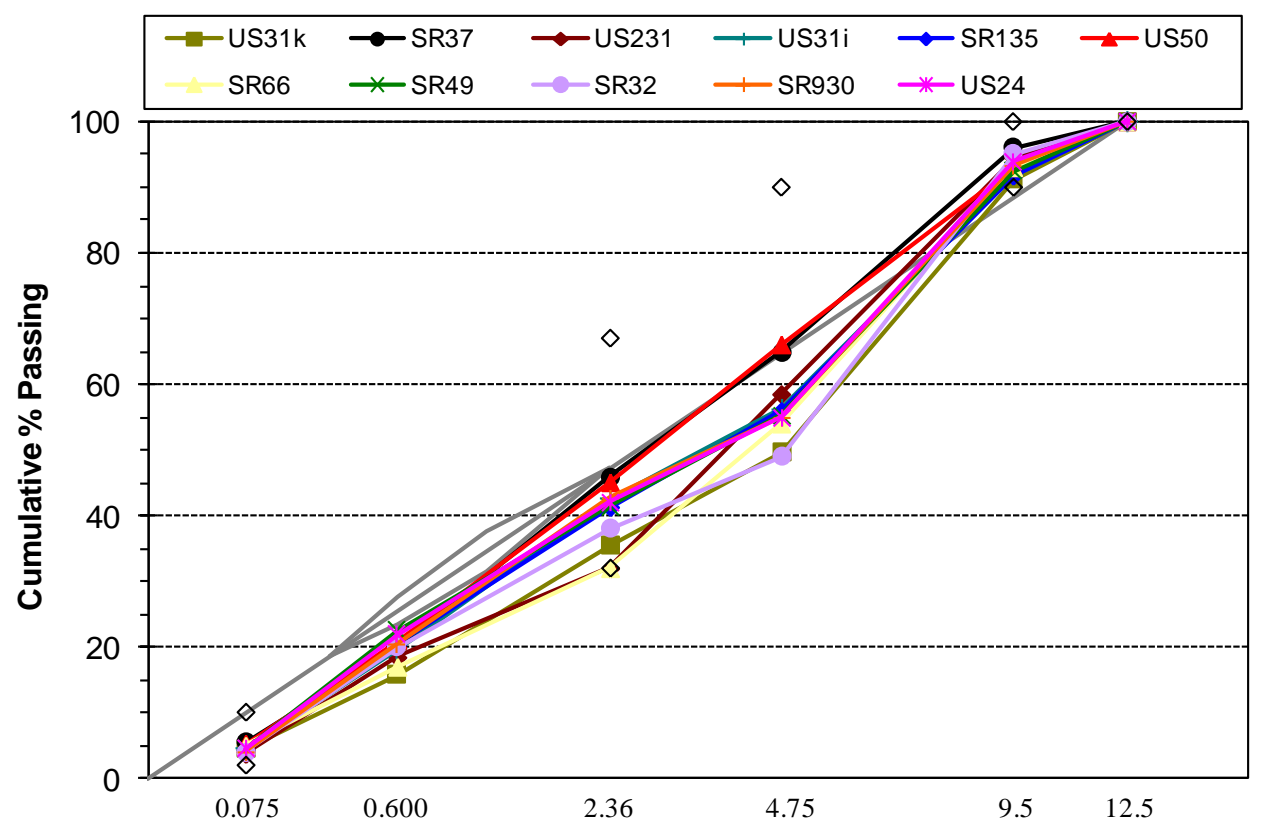

Sieve Sizes, mm

Figure 1 Mixes with $9.5 \mathrm{~mm}$ NMAS

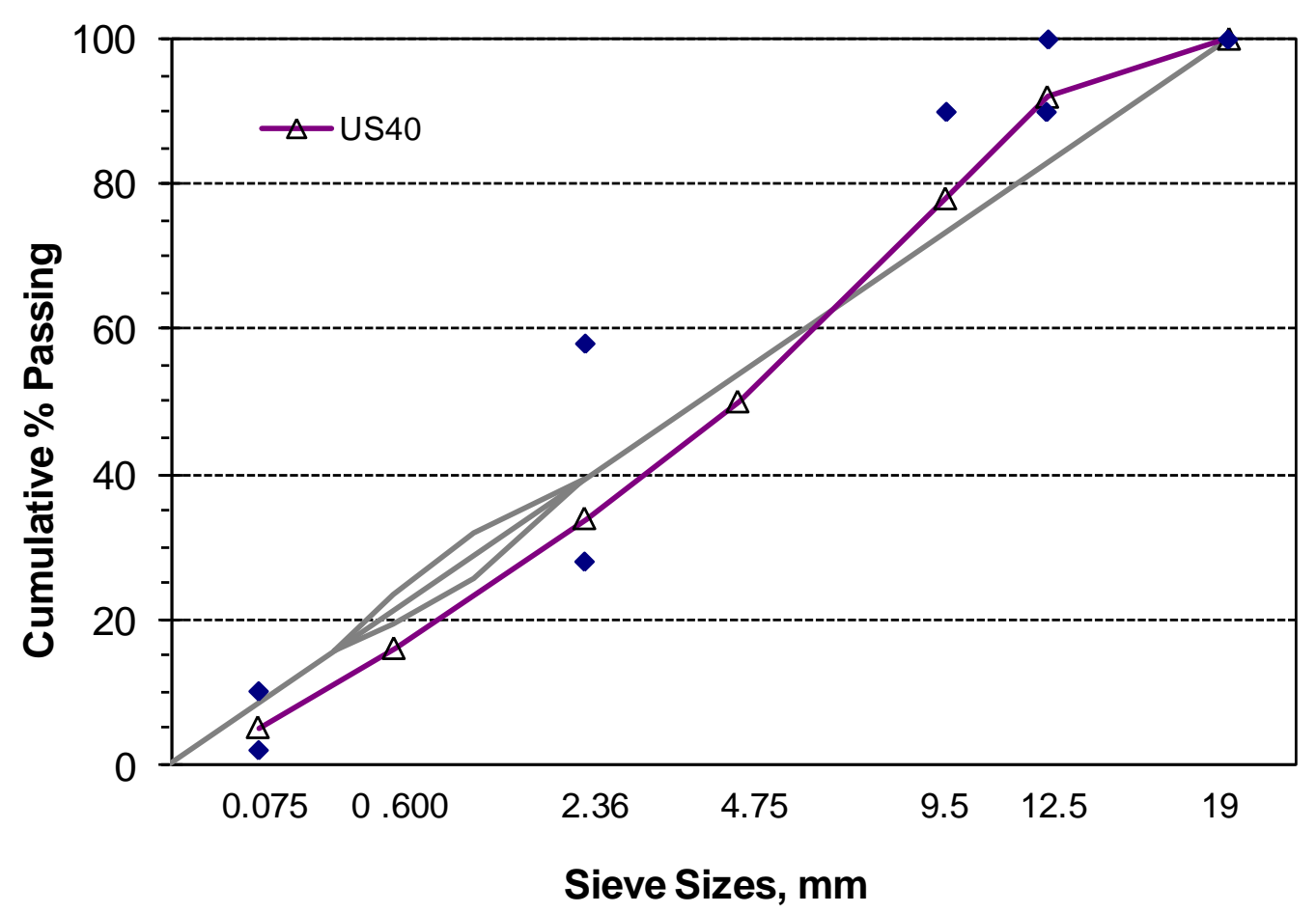

Figure 2 Mix with 12.5 mm NMAS 


\section{PART 2 TEST PROGRAM}

Tests conducted on the mixes sampled in Part 2 included maximum theoretical specific gravity $\left(\mathrm{G}_{\mathrm{mm}}\right)$ and bulk specific gravity using the traditional AASHTO T166 and T209 methods, respectively, and the vacuum-sealing method using the CoreLok as specified in ASTM D 6857 and AASHTO T331, respectively. This was done to provide a comparison between the two test methods, in continuation of the earlier part of the study.

In addition, mixture performance tests at high and low temperatures were also conducted on plant-mix samples compacted in the laboratory to $7 \pm 0.5 \%$ air voids or $3 \pm 0.5 \%$ air voids (for the repeated shear test). The Frequency Sweep at Constant Height (FSCH), Simple Shear at Constant Height (SSCH) and the Repeated Shear at Constant Height (RSCH) performance tests were conducted at intermediate to high temperatures. These tests were conducted in accordance with AASHTO T320. Creep compliance testing was conducted at $-20^{\circ} \mathrm{C},-10^{\circ} \mathrm{C}$ and $0^{\circ} \mathrm{C}$, and indirect tensile strength testing was conducted at $-10^{\circ} \mathrm{C}$, in accordance with AASHTO T322. Three replicates were tested in each of the high and low temperature performance tests.

\subsection{Specific Gravity}

The maximum theoretical specific gravity of the mixes was determined on two replicate samples using both the conventional and the CoreLok methods. The average values and standard

deviation are presented in Table 10. The $\mathrm{G}_{\mathrm{mm}}$ obtained from all mixes showed good repeatability (within mixes) as indicated by the low standard deviation values. This test was not conducted on the three mixes obtained in 2002 (US40, SR66 and SR135). 
Table 10 Average maximum theoretical specific gravity of the mixes

\begin{tabular}{|c|c|c|c|c|c|c|c|}
\hline \multirow{2}{*}{ Site ID } & \multirow{2}{*}{ Binder } & \multirow{2}{*}{$\mathbf{N}_{\text {des }}$} & \multicolumn{2}{c|}{$\begin{array}{c}\text { Conventional } \\
\text { AASHTO T166 }\end{array}$} & $\begin{array}{c}\text { CoreLok } \\
\text { ASTM D 6857 }\end{array}$ & \multirow{2}{*}{$\begin{array}{c}\text { p- } \\
\text { value* }\end{array}$} \\
\cline { 4 - 7 } & & & Ave. & Std Dev & Ave. & Std Dev & \\
\hline SR37 & PG64-22 & 75 & 2.491 & 0.006 & 2.485 & 0.014 & 0.6764 \\
\hline US40 & PG64-22 & 100 & \multicolumn{7}{|c|}{ Not tested } \\
\hline US231 & PG70-22 & 75 & 2.475 & 0.002 & 2.478 & 0.002 & 0.3308 \\
\hline US50 & PG70-22 & 75 & 2.431 & 0.007 & 2.401 & 0.046 & 0.4655 \\
\hline SR66 & PG70-22 & 100 & \multicolumn{7}{|c|}{ Not tested } \\
\hline US31k & PG70-22 & 100 & 2.418 & 0.004 & 2.426 & 0.002 & 0.1393 \\
\hline US31i & PG70-22 & 100 & 2.696 & 0.001 & 2.694 & 0.012 & 0.8919 \\
\hline SR135 & PG70-22 & 100 & \multicolumn{7}{|c|}{ Not tested } \\
\hline SR49 & PG70-28 & 100 & 2.445 & 0.002 & 2.482 & 0.001 & $\mathbf{0 . 0 0 2 3}$ \\
\hline US24 & PG76-22 & 100 & 2.515 & 0.070 & 2.499 & 0.004 & 0.7801 \\
\hline SR32 & PG76-22 & 100 & 2.419 & 0.001 & 2.425 & 0.004 & 0.1744 \\
\hline SR930 & PG76-22 & 125 & 2.792 & 0.007 & 2.806 & 0.007 & 0.1762 \\
\hline
\end{tabular}

* Bold italics indicates significant difference, P-value $\leq 0.05$.

Statistical analysis was conducted on the $\mathrm{G}_{\mathrm{mm}}$ data to determine if the two test methods influenced the outcome (data). No statistically significant differences were observed between the $\mathrm{G}_{\mathrm{mm}}$ obtained from the conventional method and the CoreLok method in all the mixes tested, except one. These findings coincide with the general conclusions obtained in Part 1 of the study. Data from SR49 showed statistically significant differences between the two methods.

Three replicate samples of each mixture were compacted to $\mathrm{N}_{\text {des }}$ using the Pine Superpave Gyratory Compactor. The bulk specific gravity $\left(\mathrm{G}_{\mathrm{mb}}\right)$ of the compacted samples was determined using the CoreLok followed by the conventional method. The average and standard deviation of the three replicates tested for each mix are shown in Table 11. 
Table 11 Average bulk specific gravity of the mixes at $\mathrm{N}_{\text {des }}$

\begin{tabular}{|c|c|c|c|c|c|c|c|}
\hline \multirow{2}{*}{ Site ID } & \multirow{2}{*}{ Binder } & \multirow{2}{*}{$\mathbf{N}_{\text {des }}$} & \multicolumn{2}{c|}{$\begin{array}{c}\text { Conventional } \\
\text { AASHTO T209 }\end{array}$} & $\begin{array}{c}\text { CoreLok } \\
\text { AASHTO T331 }\end{array}$ & \multirow{2}{*}{$\begin{array}{c}\text { p- } \\
\text { value* }\end{array}$} \\
\cline { 4 - 7 } & & & Ave. & Std Dev & Ave. & Std Dev & \\
\hline SR37 & PG64-22 & 75 & 2.360 & 0.009 & 2.350 & 0.009 & 0.2304 \\
\hline US40 & PG64-22 & 100 & \multicolumn{7}{|c|}{ Not tested } \\
\hline US231 & PG70-22 & 75 & 2.357 & 0.008 & 2.340 & 0.013 & 0.1287 \\
\hline US50 & PG70-22 & 75 & 2.317 & 0.003 & 2.308 & 0.003 & $\mathbf{0 . 0 3 3 9}$ \\
\hline SR66 & PG70-22 & 100 & \multicolumn{7}{|c|}{ Not tested } \\
\hline US31k & PG70-22 & 100 & 2.246 & 0.004 & 2.225 & 0.003 & 0.0013 \\
\hline US31i & PG70-22 & 100 & 2.577 & 0.009 & 2.569 & 0.010 & 0.3823 \\
\hline SR135 & PG70-22 & 100 & \multicolumn{7}{|c|}{ Not tested } \\
\hline SR49 & PG70-28 & 100 & 2.352 & 0.003 & 2.344 & 0.002 & $\mathbf{0 . 0 2 2 1}$ \\
\hline US24 & PG76-22 & 100 & 2.366 & 0.005 & 2.355 & 0.007 & 0.0890 \\
\hline SR32 & PG76-22 & 100 & 2.285 & 0.001 & 2.265 & 0.002 & $\mathbf{0 . 0 0 0 1}$ \\
\hline SR930 & PG76-22 & 125 & 2.708 & 0.005 & 2.699 & 0.005 & 0.1089 \\
\hline
\end{tabular}

* Bold italics indicates significant difference, P-value $\leq 0.05$.

All replicates tested showed low variability (low standard deviation) within each mix in both the test methods. The mix from SR930, which was designed for the highest traffic volume, had the highest $\mathrm{G}_{\mathrm{mb}}$. One-way ANOVA (level of significance, $\alpha=0.05$ ) was used to test the variance in $\mathrm{G}_{\mathrm{mb}}$ obtained using the two test methods. The null hypothesis tested was that there were no significant differences in the mean $\mathrm{G}_{\mathrm{mb}}$ obtained using the two test methods. A low p-value (less than 0.05) indicates that the null hypothesis must be rejected (i.e. the mixes are significantly different). Of the nine mixes tested, four mixes showed a difference between the two test methods (see Table 10).

The average air void contents were determined based on the measured maximum and bulk specific gravities. (These results are shown in Appendix B.) The air void contents were generally within $4.0 \pm 1.0 \%$ with only a few exceptions having higher air voids. The lowest air void content measured was 3.0\% (for SR930) and the highest was 7.2\% (for US31k). The air voids were measured on samples of mix reheated and compacted in the laboratory at the Division of Research, however, so these values may not be representative of the values measured at the plant.

\subsection{Indirect Tensile Strength}

The resistance to thermal cracking of bituminous materials can be assessed by determining the creep compliance and indirect tensile strength of the mixes according to AASHTO T322, 
Standard Method of Test for Determining the Creep Compliance and Strength of Hot Mix Asphalt (HMA) Using the Indirect Tensile Test Device. Creep compliance testing is conducted at $0^{\circ} \mathrm{C},-10^{\circ} \mathrm{C}$ and $-20^{\circ} \mathrm{C}$ for a period of $100 \mathrm{~s}$, while the strength test is conducted at $-10^{\circ} \mathrm{C}$. Three replicate specimens, compacted to $7 \% \pm 0.5$ air void content and with dimensions $50 \mathrm{~mm}$ high $\mathrm{x} 150 \mathrm{~mm}$ diameter, were tested at each temperature. The data were then used to generate the thermal stress curve using an algorithm titled LTSTRESS, developed by Don Christensen (1). Thermal cracking is assumed to occur at the temperature when the thermal stresses in the pavement exceed the indirect tensile strength of the mix. This temperature is called the critical cracking temperature $\left(\mathrm{T}_{\text {critical }}\right)$ of the mix. In addition to the tensile strength of the mixtures, the compliance (or stiffness) of the mixtures is also important in determining the critical cracking temperature of the mixes. An optimum combination of high tensile strength and low creep stiffness is crucial for better thermal cracking resistance.

Table 12 shows the average strengths, critical cracking temperatures and stiffnesses of the mixtures. The tensile strengths of the mixes tested ranged between $3912 \mathrm{kPa}$ and $5314 \mathrm{kPa}$. Mixes with minimum strength of $3448 \mathrm{kPa}(500 \mathrm{psi})$ at $-10^{\circ} \mathrm{C}$ are generally considered acceptable. All the mixes in this study met this requirement. The strength of a mix, at a given temperature, is influenced by the gradation, binder grade, aggregate type and design ESALs. Hence, no clear cut trends are evident among the mixes tested, at first glance.

Table 12 Average tensile strengths and stiffnesses of the mixes

\begin{tabular}{|c|c|c|c|c|c|}
\hline Site ID & Binder & $\begin{array}{c}\text { ESALs } \\
(\mathbf{m i l l i o n s})\end{array}$ & $\begin{array}{c}\mathbf{T}_{\text {crit }} \\
{ }^{\mathbf{o}} \mathbf{C}\left({ }^{\mathbf{G}}\right)\end{array}$ & $\begin{array}{c}\text { Strength } \\
\mathbf{k P a}(\mathbf{p s i})\end{array}$ & $\begin{array}{c}\text { Stiffness at 60 s } \\
\mathbf{G P a}(\mathbf{x ~ 1 0} \mathbf{\text { psi}})\end{array}$ \\
\hline SR37 & PG64-22 & 1.5 & $-24(-11)$ & $4059(589)$ & $18.5(2.68)$ \\
\hline US40 & PG64-22 & $3-30$ & $-18(-0.4)$ & $4508(654)$ & $22.9(3.32)$ \\
\hline US231 & PG70-22 & 2.5 & $-17(1)$ & $3923(569)$ & $25.0(3.62)$ \\
\hline US50 & PG70-22 & 2.5 & $-19(-2)$ & $4534(657)$ & $21.4(3.10)$ \\
\hline SR66 & PG70-22 & 6.8 & $-22(-8)$ & $4605(668)$ & $18.8(2.73)$ \\
\hline US31k & PG70-22 & 11 & $-17(1)$ & $3912(567)$ & $19.0(2.76)$ \\
\hline US31i & PG70-22 & 20 & $-20(-4)$ & $4140(600)$ & $17.9(2.60)$ \\
\hline SR135 & PG70-22 & 20 & $-21(-6)$ & $4283(621)$ & $19.0(2.75)$ \\
\hline SR49 & PG70-28 & 22 & $-28(-18)$ & $4096(594)$ & $14.8(2.14)$ \\
\hline US24 & PG76-22 & 5.6 & $-18(-0.4)$ & $5314(771)$ & $23.4(3.39)$ \\
\hline SR32 & PG76-22 & 8 & $-21(-6)$ & $4267(619)$ & $20.4(2.96)$ \\
\hline SR930 & PG76-22 & 35 & $-27(-17)$ & $4595(666)$ & $16.6(2.40)$ \\
\hline
\end{tabular}

In general, it can be seen that mixes with lower stiffness have a more negative critical cracking temperature. While a high strength value is also required for improved thermal cracking 
resistance, it is the lower stiffness value that controls the $T_{\text {critical }}$, as evidenced by Figures 3 and 4 . Figure 3 shows the indirect tensile strength of the mixes and the corresponding estimated critical cracking temperature of the mixes. Of the 12 mixes tested, only four mixes had $\mathrm{T}_{\text {critical }}$ less than or equal to the low temperature binder grade of the mix. Figure 4 shows the stiffness of mixes at $60 \mathrm{~s}$ and the corresponding estimated critical cracking temperature of the mixes. It can be seen that the estimated $\mathrm{T}_{\text {critical }}$ does not follow the same trend observed in strength; in Figure 4 the $\mathrm{T}_{\text {critical }}$ line runs more or less parallel to the mixtures stiffness line whereas there was no clear correlation in Figure 3. Mixes with lower stiffness had lower (more negative) $\mathrm{T}_{\text {critical }}$ and vice versa.

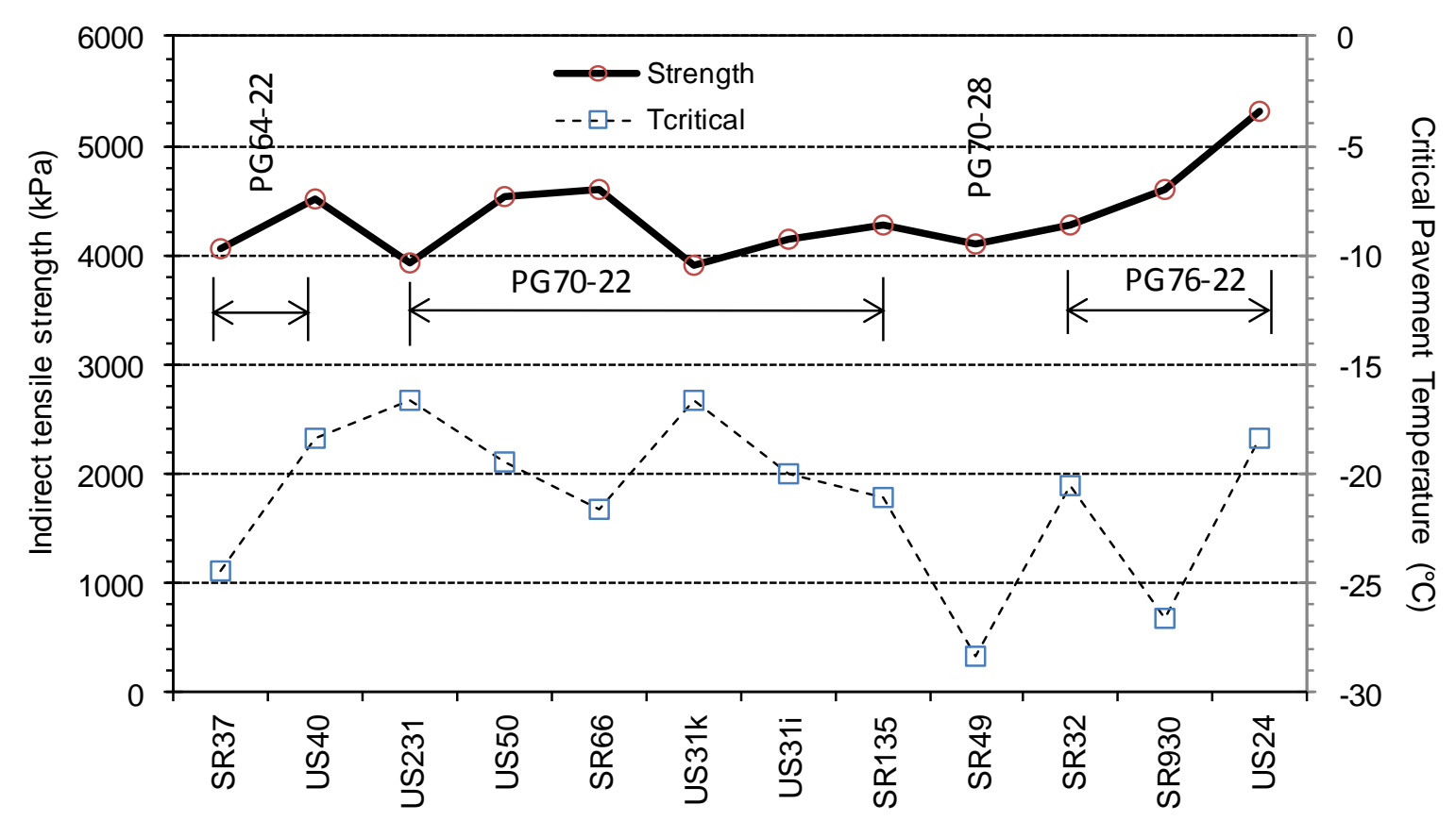

Figure 3 Indirect tensile strength and $\mathrm{T}_{\text {critical }}$ of the mixes 


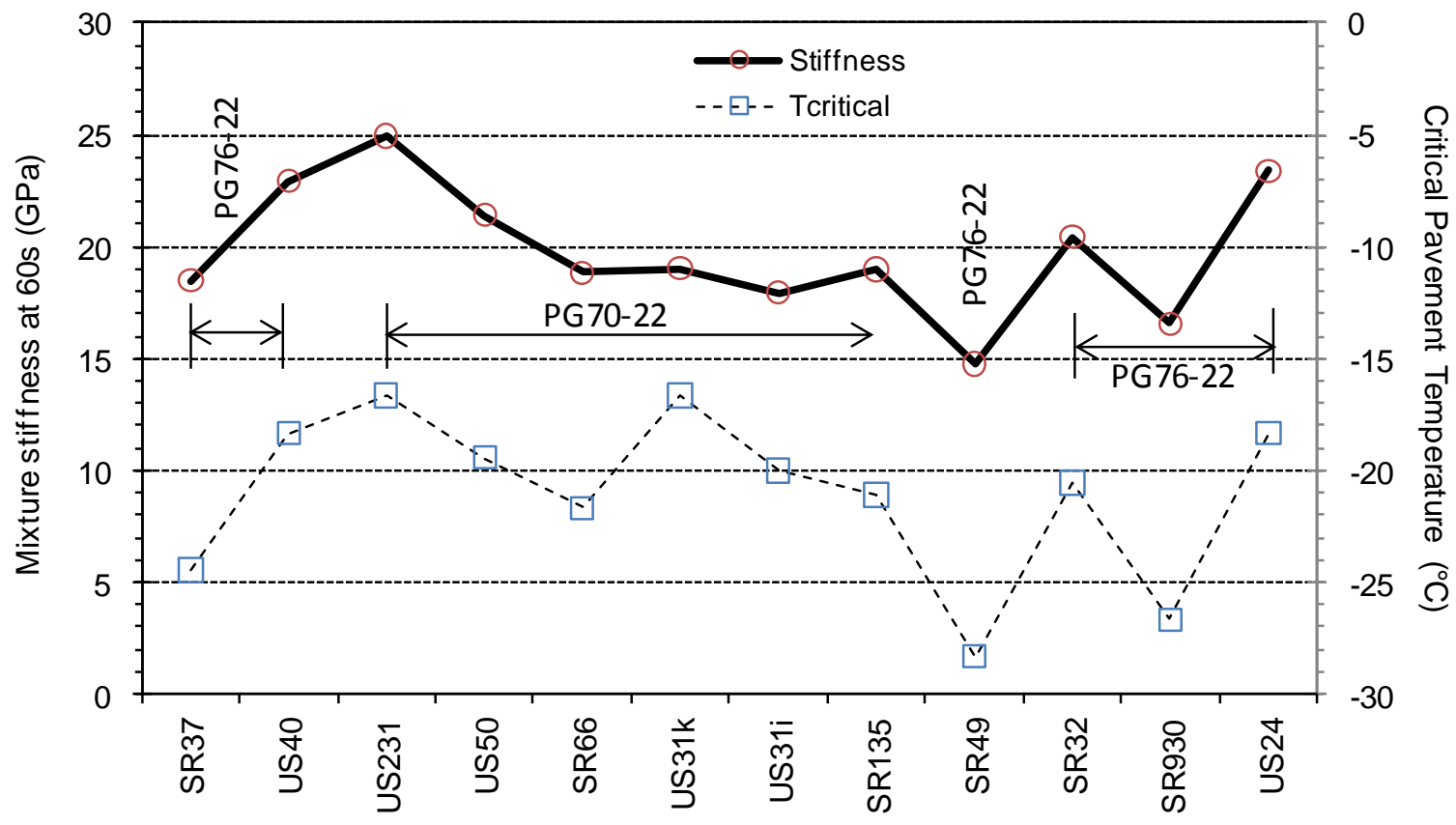

Figure 4 Stiffness and $\mathrm{T}_{\text {critical }}$ of the mixes

Statistical analysis using the Analysis of Variance (ANOVA) method was conducted to determine the influence of binder grade on the strength of the mixes. The hypotheses tested and pvalues are shown in Table 13. Ignoring differences in gradation and design ESALs, the data were sorted into groups with the same binder grade. ANOVA comparison of the mean strengths of mixes with the same binder grade indicated that the mixes were significantly different. Further testing using the Bonferroni multiple comparison of means method, however, did not yield clear groupings among the mixes. This may be attributed to the compounding factor of different design ESALs for the mixes within each binder group.

Table 13 Statistical analysis on indirect tensile strength of the mixes

\begin{tabular}{|c|c|c|c|}
\hline Hypothesis & Binder & p-value & Conclusion \\
\hline$\mu_{\mathrm{SR} 37}=\mu_{\mathrm{US} 40}$ & $\mathrm{PG} 64-22$ & 0.0342 & $\begin{array}{c}\text { Mean strengths are } \\
\text { significantly different }\end{array}$ \\
\hline $\begin{array}{c}\mu_{\mathrm{US} 231}=\mu_{\mathrm{US} 50}=\mu_{\mathrm{SR} 66}=\mu_{\mathrm{US} 31 \mathrm{k}}= \\
\mu_{\mathrm{US} 31 \mathrm{i}}=\mu_{\mathrm{SR} 135}\end{array}$ & $\mathrm{PG} 70-22$ & 0.0198 & $\begin{array}{c}\text { Mean strengths are } \\
\text { significantly different }\end{array}$ \\
\hline$\mu_{\mathrm{US} 24}=\mu_{\mathrm{SR} 32}=\mu_{\mathrm{SR} 930}$ & $\mathrm{PG} 76-22$ & 0.0101 & $\begin{array}{c}\text { Mean strengths are } \\
\text { significantly different }\end{array}$ \\
\hline
\end{tabular}


Similar analysis was conducted after dividing the sites based on the design ESAL groupings given by AASHTO. Accordingly, the three groups formed were as follows:

Group 1 ( 0.3 to $<3$ million ESALs):

Group 2 (3 to $<10$ million ESALs):

Group 3 (10 to <30 million ESALs):
SR37, US231, US50

US24, SR66, SR32

US31k, US31i, SR135, SR49

US 40 and SR930 were not included in the analysis as they fell into two separate categories (no replicate sites). ANOVA on the complete set of data from the ten sites indicated that there were significant differences in the mean strengths of the three groups. A Bonferroni comparison of means test indicated that the mean strength of group 2 was different from that of groups 1 and 3, but groups 1 and 3 could not be differentiated from each other, as shown in Table 14.

Table 14 Statistical analysis of IDT strength based on ESAL classification

\begin{tabular}{|c|c|c|c|}
\hline Hypothesis & p-value & Conclusion & Bonferroni grouping \\
\hline$\mu_{\text {group } 1}=\mu_{\text {group } 2}=\mu_{\text {group } 3}$ & 0.0000 & $\begin{array}{c}\text { Mean strengths are } \\
\text { significantly different }\end{array}$ & $\begin{array}{c}\text { [Group2]; } \\
\text { [Group1, Group3] }\end{array}$ \\
\hline
\end{tabular}

Further detailed analysis was conducted to investigate whether sites within each ESAL group had similar strengths. Table 15 shows the hypothesis and the p-value obtained for each ESAL group. For groups that showed significant differences, Bonferroni groupings of the mean strength of the sites are also shown in this table. There are two overlapping groupings for the lowest ESAL category such that no clear distinction can be made between the groups. For the second ESAL level, US24 is significantly different from SR66 and SR32, but the reason for this is not obvious; US24 and SR32 both had PG76-22 binder while SR66 had a PG70-22. This analysis underscores the fact that the behavior of a mixture is a result of a complex interaction of multiple factors.

Table 15 Statistical analysis of IDT strength within each ESAL group

\begin{tabular}{|c|c|c|c|}
\hline Hypothesis & p-value & Conclusion & Bonferroni grouping \\
\hline$\mu_{\mathrm{SR} 37}=\mu_{\mathrm{US} 231}=\mu_{\mathrm{US} 50}$ & 0.0148 & $\begin{array}{c}\text { Mean strengths are } \\
\text { significantly different }\end{array}$ & $\begin{array}{c}{[\mathrm{US} 50, \mathrm{SR} 37] ;} \\
{[\mathrm{SR} 37, \mathrm{US} 231]}\end{array}$ \\
\hline$\mu_{\mathrm{US} 24}=\mu_{\mathrm{SR} 66}=\mu_{\mathrm{SR} 32}$ & 0.0016 & $\begin{array}{c}\text { Mean strengths are } \\
\text { significantly different }\end{array}$ & $\begin{array}{c}{[\mathrm{US} 24] ;} \\
{[\mathrm{SR} 66, \mathrm{SR} 32]}\end{array}$ \\
\hline $\begin{array}{c}\mu_{\mathrm{US} 31 \mathrm{k}}=\mu_{\mathrm{US} 31 \mathrm{i}}=\mu_{\mathrm{SR} 135}= \\
\mu_{\mathrm{SR} 49}\end{array}$ & 0.5872 & $\begin{array}{c}\text { No significant differences } \\
\text { in mean modulus }\end{array}$ & N/A \\
\hline
\end{tabular}




\subsection{Superpave Shear Tests}

Samples of the mixes were compacted in the Pine gyratory and sawed to produce $50 \mathrm{~mm}$ high specimens for testing according to AASHTO T320, Standard Method of Test for Determining the Permanent Shear Strain and Complex Shear Modulus of Asphalt Mixtures using the Superpave Shear Tester (SST). Samples were compacted to $7 \pm 0.5 \%$ air voids except for those for the Repeated Shear at Constant Height test, which is performed at $3 \pm 0.5 \%$ voids.

\subsubsection{Frequency Sweep at Constant Height}

Frequency sweep testing was conducted at $20^{\circ} \mathrm{C}$ and $40^{\circ} \mathrm{C}$ to determine the shear stiffness of the mixtures under repeated loading conditions. The test sample was held between two metal platens and subjected to sinusoidal shear strain cycles of $0.0001 \mathrm{~mm} / \mathrm{mm}$ amplitude at different frequencies which simulate different traffic loads/speeds. The shear load required to maintain this level of strain and the corresponding axial load required to maintain constant height were recorded, along with the phase angle between the applied shear strain and the resulting shear load. These data were used to calculate the complex shear moduli, $\left|\mathrm{G}^{*}\right|$, for corresponding frequencies, which were saved in the output file along with the phase angle and other parameters.

The complex shear moduli $\left(\left|\mathrm{G}^{*}\right|\right)$ of the mixes at $10 \mathrm{~Hz}$ were used in making statistical comparisons between the mixes. Figures 5 and 6 show the $\left|\mathrm{G}^{*}\right|$ at $10 \mathrm{~Hz}$ at $20^{\circ} \mathrm{C}$ and $40^{\circ} \mathrm{C}$. As expected, the moduli of the mixes were higher at the lower test temperature $\left(20^{\circ} \mathrm{C}\right)$ than at the higher test temperature $\left(40^{\circ} \mathrm{C}\right)$. At lower test temperatures, the influence of binder grade becomes more significant when compared with results at higher test temperatures where the aggregate gradation/interlocking is more significant. Table 16 summarizes the average values and the coefficients of variation of the mixes at $10 \mathrm{~Hz}$ at the two test temperatures.

Based on guidelines recommended by the Asphalt Institute, mixtures with $\left|\mathrm{G}^{*}\right|$ less than 22,000 psi at $40^{\circ} \mathrm{C}$ may be expected to show "poor" resistance to rutting in the field. Field performance of mixtures with $\left|G^{*}\right|$ between 22,000 and 35,000 psi may be considered "fair" and that of mixes with $\left|\mathrm{G}^{*}\right|$ greater than 35,000 psi may be considered "excellent." (2) Since all the mixes had $\left|\mathrm{G}^{*}\right|$ greater than $35000 \mathrm{psi}$, all the mixes tested in this study may be expected to show low rutting in the field. 


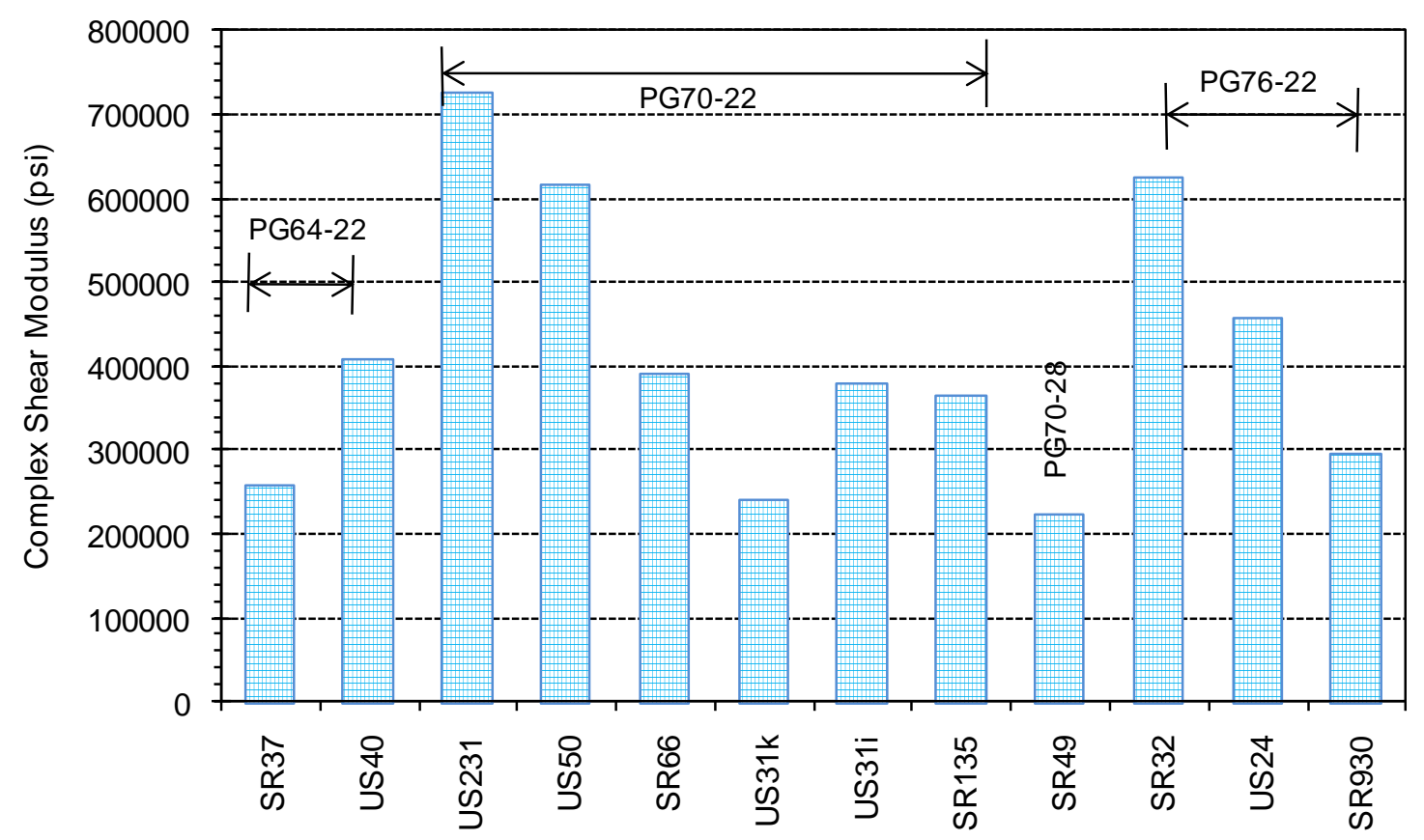

Figure 5 Frequency sweep at $10 \mathrm{~Hz}$ at $20^{\circ} \mathrm{C}$

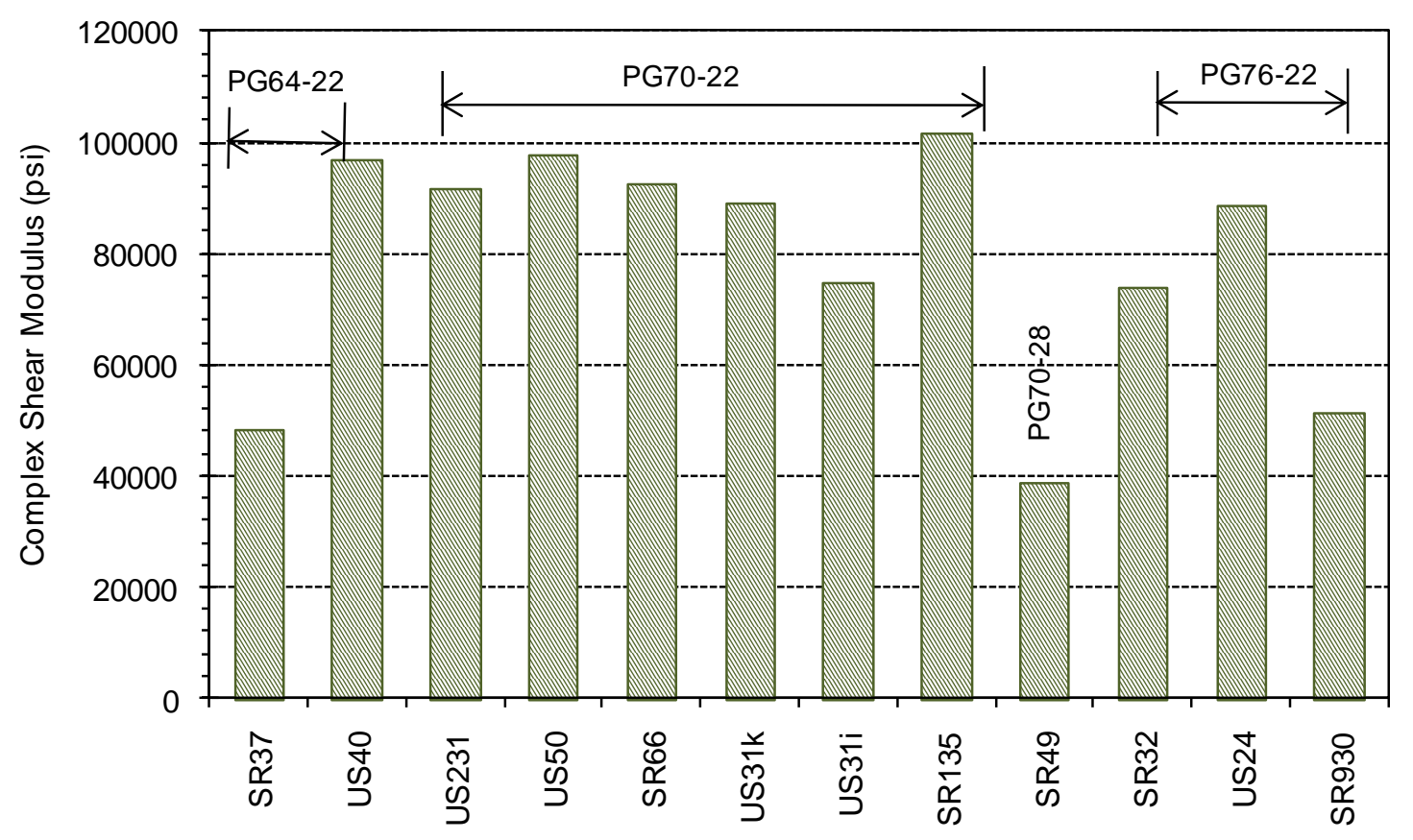

Figure 6 Frequency sweep at $10 \mathrm{~Hz}$ at $40^{\circ} \mathrm{C}$ 
Table 16 Average complex shear moduli of the mixes

\begin{tabular}{|c|c|c|c|c|c|c|}
\hline \multirow{2}{*}{ Site ID } & \multirow{2}{*}{ Binder } & \multirow{2}{*}{$\begin{array}{c}\text { ESALs } \\
\text { (millions) }\end{array}$} & \multicolumn{2}{|c|}{ At $20^{\circ} \mathrm{C}$} & \multicolumn{2}{|c|}{ At $40^{\circ} \mathrm{C}$} \\
\hline & & & $|\mathrm{G} *|$, psi & C. V., \% & $\left|G^{*}\right|$, psi & C. V., \% \\
\hline SR37 & PG64-22 & 1.5 & 259370 & 12.1 & 48062 & 3.2 \\
\hline US40 & PG64-22 & $3-30$ & 408904 & 2.7 & 96588 & 4.5 \\
\hline US231 & PG70-22 & 2.5 & 727307 & 27.6 & 91811 & 11.0 \\
\hline US50 & PG70-22 & 2.5 & 616500 & 15.6 & 97566 & 17.5 \\
\hline SR66 & PG70-22 & 6.8 & 392405 & 15.0 & 92480 & 21.7 \\
\hline US31k & PG70-22 & 11 & 241343 & 9.7 & 88783 & 2.3 \\
\hline US31i & PG70-22 & 20 & 380783 & 20.4 & 74830 & 8.9 \\
\hline SR135 & PG70-22 & 20 & 364558 & 19.6 & 101396 & 15.0 \\
\hline SR49 & PG70-28 & 22 & 223777 & 9.7 & 38545 & 8.6 \\
\hline US24 & PG76-22 & 5.6 & 458284 & 18.9 & 88462 & 13.3 \\
\hline SR32 & PG76-22 & 8 & 625110 & 0.8 & 73808 & 19.0 \\
\hline SR930 & PG76-22 & 35 & 296642 & 4.4 & 51164 & 4.0 \\
\hline
\end{tabular}

Analysis of variance of the modulus values of mixes with similar binder grades gave mixed results. For the PG64-22 and PG76-22 binder grades, the p-values were less than 0.05, indicating that the mixes were not similar. This is not unexpected since the mixes were designed at different traffic levels with the same binder grade. For the PG70-22 grade, however, the moduli were not significantly different at $40^{\circ} \mathrm{C}$ despite the fact that the mixes represent all three traffic categories; there were significant differences between the mixes with PG70-22 at $20^{\circ} \mathrm{C}$. The reasons for this are not known. Table 17 summarizes the hypotheses tested and the corresponding p-values. However, further testing using the Bonferroni comparison of means method did not yield any common groupings among the mixtures.

Table 17 Statistical analysis of complex shear moduli of mixes

\begin{tabular}{|c|c|c|c|c|}
\hline \multirow{2}{*}{ Hypothesis } & \multirow{2}{*}{ Binder } & \multicolumn{2}{|c|}{ p-value } & \multirow{2}{*}{ Conclusion } \\
\hline & & $20^{\circ} \mathrm{C}$ & $40^{\circ} \mathrm{C}$ & \\
\hline$\mu_{\mathrm{SR} 37}=\mu_{\mathrm{US} 40}$ & PG64-22 & 0.0084 & 0.0003 & $\begin{array}{c}\text { Mean moduli are } \\
\text { significantly different }\end{array}$ \\
\hline $\begin{array}{c}\mu_{\mathrm{US} 231}=\mu_{\mathrm{US} 50}=\mu_{\mathrm{SR} 66}=\mu_{\mathrm{US} 31 \mathrm{k}}= \\
\mu_{\mathrm{US} 31 \mathrm{i}}=\mu_{\mathrm{SR} 135}\end{array}$ & PG70-22 & 0.0016 & $\begin{array}{l}0.2952 \\
(\mathrm{NSD})\end{array}$ & $\begin{array}{c}\text { Mean moduli at } \\
\text { significantly different at } \\
20^{\circ} \mathrm{C} \text { but not at } 40^{\circ} \mathrm{C}\end{array}$ \\
\hline$\mu_{\mathrm{US} 24}=\mu_{\mathrm{SR} 32}=\mu_{\mathrm{SR} 930}$ & PG76-22 & 0.0035 & 0.0143 & $\begin{array}{c}\text { Mean moduli are } \\
\text { significantly different }\end{array}$ \\
\hline
\end{tabular}

Comparison of the mean moduli (at $40^{\circ} \mathrm{C}$ ) between the three groups based on ESAL classification indicated that there were no significant differences between the groups (Table 18). 
Table 18 Statistical analysis of shear moduli based on ESAL classification

\begin{tabular}{|c|c|c|}
\hline Hypothesis & p-value & Conclusion \\
\hline$\mu_{\text {group } 1}=\mu_{\text {group } 2}=\mu_{\text {group } 3}$ & 0.5306 & $\begin{array}{c}\text { No significant differences in } \\
\text { mean modulus }\end{array}$ \\
\hline
\end{tabular}

To investigate differences between sites within each ESAL group, analyses similar to that mentioned in the IDT section were conducted. Results from these analyses are presented in Table 19.

Table 19 Statistical analysis of shear moduli within each ESAL group

\begin{tabular}{|c|c|c|c|}
\hline Hypothesis & p-value & Conclusion & Bonferroni grouping \\
\hline$\mu_{\mathrm{SR} 37}=\mu_{\mathrm{US} 231}=\mu_{\mathrm{US} 50}$ & 0.0036 & $\begin{array}{c}\text { Mean strengths are } \\
\text { significantly different }\end{array}$ & $\begin{array}{c}{[\mathrm{US} 50, \mathrm{US} 231] ;} \\
\text { [SR37] }\end{array}$ \\
\hline$\mu_{\mathrm{US} 24}=\mu_{\mathrm{SR} 66}=\mu_{\mathrm{SR} 32}$ & 0.3706 & $\begin{array}{c}\text { No significant differences } \\
\text { in mean modulus }\end{array}$ & $\mathrm{N} / \mathrm{A}$ \\
\hline $\begin{array}{c}\mu_{\mathrm{US} 31 \mathrm{k}}=\mu_{\mathrm{US} 31 \mathrm{i}}=\mu_{\mathrm{SR} 135}= \\
\mu_{\mathrm{SR} 49}\end{array}$ & 0.0001 & $\begin{array}{c}\text { Mean strengths are } \\
\text { significantly different }\end{array}$ & $\begin{array}{c}{[\mathrm{SR} 135, \mathrm{US} 31 \mathrm{k}] ;} \\
{[\mathrm{US} 31 \mathrm{k}, \mathrm{US} 31 \mathrm{i}] ;} \\
\text { [SR49] }\end{array}$ \\
\hline
\end{tabular}

Again, there is no obvious reason for the different Bonferroni groupings. Mixtures with the same binder grade fell into different groups in some cases and not in others. The shear modulus is a function of more than just the traffic category and/or the binder grade, but rather is a complex interaction of multiple variables.

\subsubsection{Simple Shear at Constant Height}

At the end of the FSCH test, the Simple Shear at Constant Height (SSCH) test was conducted on the same specimen at both test temperatures. In this test, a static shear stress was applied at a rate of $70 \mathrm{kPa} / \mathrm{s}$ until a maximum stress $\left(105 \mathrm{kPa}\right.$ at $20^{\circ} \mathrm{C}$ and $35 \mathrm{kPa}$ at $\left.40^{\circ} \mathrm{C}\right)$ was attained, then it was held constant for $10 \mathrm{~s}$. After $10 \mathrm{~s}$, the shear stress was decreased at a rate of $25 \mathrm{kPa} / \mathrm{s}$ and held at 0 $\mathrm{kPa} / \mathrm{s}$ for $10 \mathrm{~s}$. Constant specimen height was maintained throughout the test by adjusting the axial stress. The resultant shear strain was recorded as a function of time and of the corresponding axial and shear stresses.

Figure 7 shows a plot of the shear strain as a function of time at $40^{\circ} \mathrm{C}$. Mixes from SR49, US31k, SR66, SR37 and US40 appear to be softer than the other mixes as indicated by their flat peak regions, where the strains exceeded the range of the LVDT. Of these, SR37 and US40 had the softest binder grade (PG64-22). None of the mixes (US24, SR 32 and SR930) having the stiffest grade 
(PG76-22) failed (flat-lined) at this temperature, i.e., the shear deformation did not exceed the LVDT limit/range.

The amount of permanent strain accumulated in the sample may be determined by taking the ratio of the remaining strain at the end of the test to the maximum strain. High values would indicate that the mix would have a lower ability to recover its original shape after the applied shear load was removed (e.g., due to passing vehicles). Table 20 presents the maximum strain level and percent permanent strain for the mixes tested.

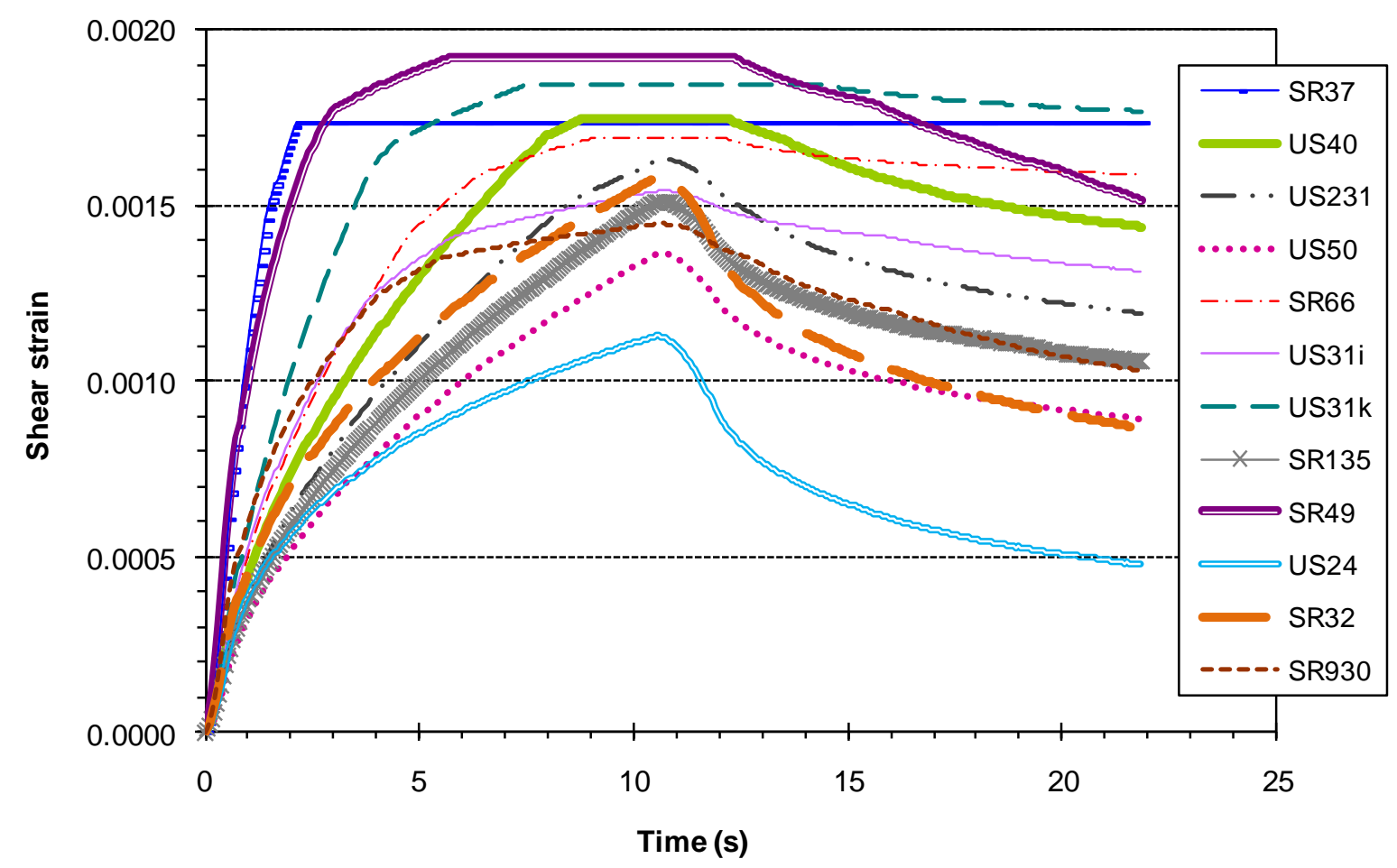

Figure 7 Simple Shear at $40^{\circ} \mathrm{C}$

As indicated by the data and graph, it may be expected that mixes with the flat peak strain mentioned earlier (SR37, US40, SR66, SR49 and US31k) and those with high values of permanent strain (SR37, SR66 and US31k) would show poorer performance in terms of rutting relative to the other sites (mixes). It should be noted, however, that this test is not considered to be as meaningful as the other shear tests, largely because it is a single loading event rather than a repeated load; the test typically has higher variability than the repeated load tests. (In fact, the current ASTM version of the SST test protocol (D7312) does not include the simple shear test for this very reason.) 
Table 20 Maximum and percent permanent shear strain

\begin{tabular}{|c|c|c|c|c|c|c|}
\hline \multirow{2}{*}{ Site ID } & \multirow{2}{*}{ Binder } & \multirow{2}{*}{$\begin{array}{c}\text { ESALs } \\
\text { (millions) }\end{array}$} & \multicolumn{2}{|c|}{ At $20^{\circ} \mathrm{C}$} & \multicolumn{2}{|c|}{ At $40^{\circ} \mathrm{C}$} \\
\hline & & & Max. $\gamma$ & $\gamma_{\text {perm }}, \%$ & Max. $\gamma$ & $\gamma_{\text {perm }}, \%$ \\
\hline SR37 & PG64-22 & 1.5 & 0.00043 & 53.8 & 0.0017 & 100.0 \\
\hline US40 & PG64-22 & $3-30$ & 0.00021 & 41.5 & 0.0017 & 82.4 \\
\hline US231 & PG70-22 & 2.5 & 0.00020 & 39.4 & 0.0016 & 73.2 \\
\hline US50 & PG70-22 & 2.5 & 0.00016 & 42.0 & 0.0014 & 65.5 \\
\hline SR66 & PG70-22 & 6.8 & 0.00024 & 40.9 & 0.0017 & 93.9 \\
\hline US31k & PG70-22 & 11 & 0.00076 & 67.4 & 0.0018 & 95.8 \\
\hline US31i & PG70-22 & 20 & 0.00017 & 41.8 & 0.0015 & 85.2 \\
\hline SR135 & PG70-22 & 20 & 0.00022 & 41.6 & 0.0015 & 69.9 \\
\hline SR49 & PG70-28 & 22 & 0.00050 & 48.9 & 0.0019 & 78.9 \\
\hline US24 & PG76-22 & 5.6 & 0.00023 & 42.9 & 0.0011 & 42.4 \\
\hline SR32 & PG76-22 & 8 & 0.00021 & 37.6 & 0.0016 & 54.9 \\
\hline SR930 & PG76-22 & 35 & 0.00030 & 43.6 & 0.0014 & 71.0 \\
\hline
\end{tabular}

\subsubsection{Repeated Shear at Constant Height}

This test gives a measure of the susceptibility of mixes to tertiary (plastic) flow when subjected to repeated shear loads at higher temperatures. This test is typically conducted at an effective pavement temperature associated with rutting or permanent deformation $\left(\mathrm{T}_{\text {eff(}(\mathrm{PD})}\right)$ on field core samples or lab samples compacted to $3 \pm 0.5 \%$ air voids. This test is considered to reflect the susceptibility of a mixture to tertiary flow if its air voids decrease to a low level under traffic. The test sample is held between two platens and subjected to repeated loading cycles. Each loading cycle consists of the application of a shear stress of $69 \pm 5 \mathrm{kPa}$ for $0.1 \mathrm{~s}$ followed by a $0.9 \mathrm{~s}$ rest period. The test is terminated at the end of 5000 cycles or $5 \%$ cumulative permanent strain, whichever occurs earlier. The permanent shear strain as a function of the number of load cycles is recorded throughout the test.

Testing of all the mixture samples was conducted at $58^{\circ} \mathrm{C}$, and the results are shown in Figure 8. Mixtures with high permanent strain are prone to rutting in the field. The Asphalt Institute recommends the following guidelines for assessing the rut resistance of mixtures based on extensive lab tests. Mixes may be expected to show excellent, good or fair performance if the permanent strain is less than $1 \%$, between $1 \%$ and $2 \%$, and between $2 \%$ and $3 \%$, respectively. (2) 
Accordingly, mixes for SR66, SR37 and US231 may be expected to show poorer (though still fair) performance due to the higher permanent strain observed in these mixes, in comparison to the other mixes. Mixes from SR930 and US24 may be expected to show excellent performance. The rutting performance of the remaining mixes would be expected to fall between the abovementioned two groups.

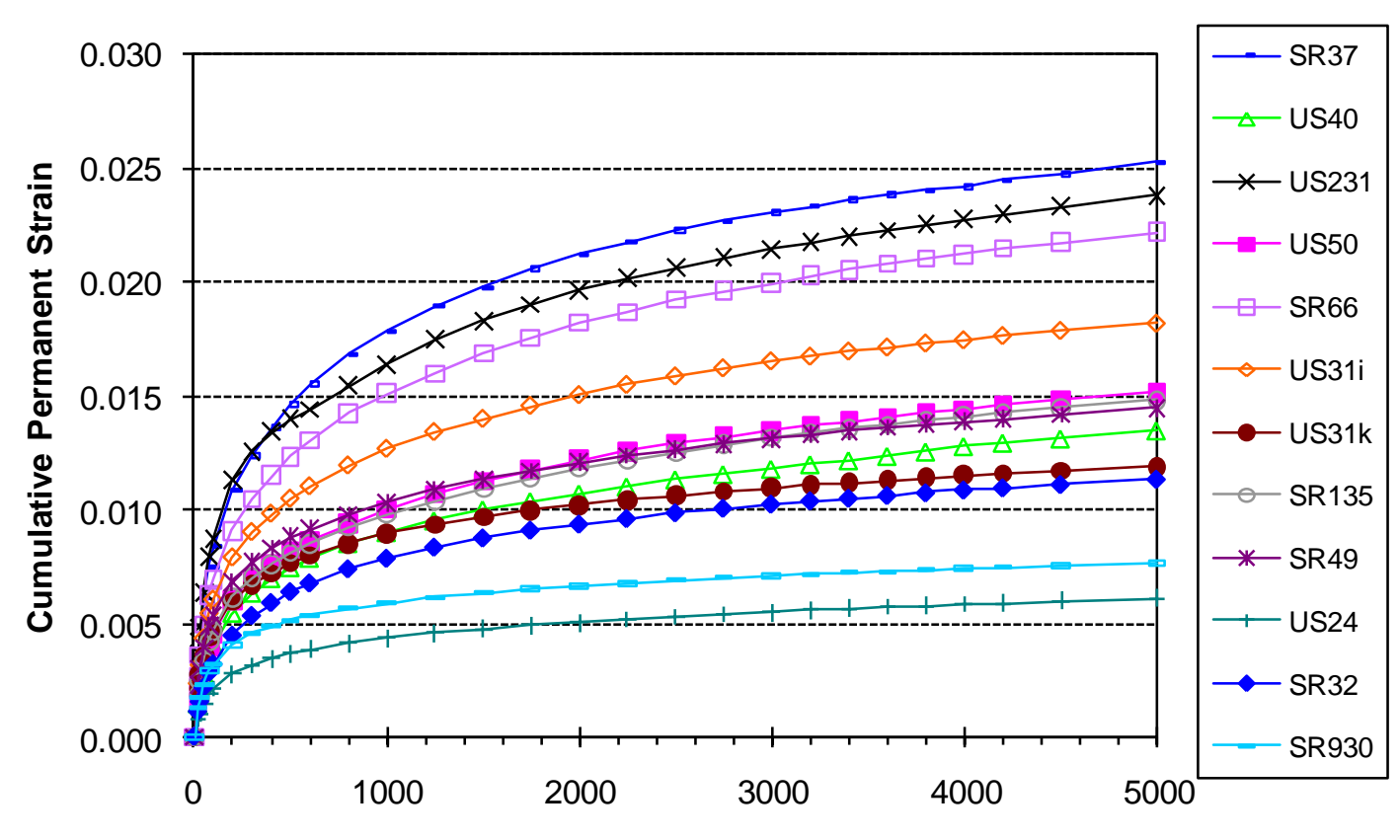

No. of Cycles

Figure 8 Repeated Shear at $58^{\circ} \mathrm{C} 3$

\subsection{Purwheel Testing}

Laboratory rutting tests using the Purwheel were originally planned to be conducted on all of the mixtures sampled in Part 2. The Purwheel applies a repeated load on slabs of mix through a pneumatic tire. The contact pressure is approximately $620 \mathrm{kPa}$ and the wheel moves at approximately $33 \mathrm{~cm} / \mathrm{s}$. The tests were conducted under water at a temperature of $60^{\circ} \mathrm{C}$. Samples were compacted in a linear compactor to approximately $7 \%$ air voids.

Continual equipment problems (mechanical and computer related), however, delayed the project significantly. Eventually it was decided, in consultation with the SAC, to attempt Purwheel testing on only a limited number of projects. The SST data was reviewed to select two projects that would be expected to perform well and two that would be expected to exhibit poorer performance. Since none of the projects had values falling in the poor performance range, the distinctions between the mixes were not great. Findings from a field condition survey in 2003 were also examined to 
detect possible differences in performance. In the end it was decided to perform Purwheel testing on samples of the mixes from US24, SR49 and SR135. Based on the SST data, as confirmed by the field data, US24 and SR135 would be expected to perform well in terms of rutting. SR49 would be expected to perform somewhat worse, based on the SST data, though still good overall.

The Purwheel testing was completed to at least 20,000 passes on two samples of each mix, but equipment problems made this testing very difficult. The machine was experiencing significant shaking when the wheels were reversed. The actual rut depth data was questionable because of this shaking. The measured rut depth showed considerable noise, and traces from one day to the next did not line up properly, making analysis of the numerical data questionable at best.

Ultimately, then, this testing did not provide useful information about the rutting performance of the mixtures evaluated. Photographs of the samples after testing, shown in Appendix C, reveal no evidence of stripping, which can occur during testing under water at high temperature in strippingprone mixtures. The ruts developed are quite small, though accurate depth measurements are not available (because of the equipment problems). Much more significant rutting has been observed with poorer mixes; rut depths exceeding $20 \mathrm{~mm}$ have been recorded when testing under the conditions used here. (3) These results, then, do not allow for statistical analysis but do suggest that the mixes evaluated would not be expected to demonstrate significant stripping or rutting in the field. (It should be noted, however, that only the surface mixes were tested; underlying layers were not tested so their tendencies to rut or strip were not evaluated.)

\subsection{Field Performance}

The field performance of the sections from Part 2 was evaluated by a condition survey in 2003 and by examination of the videologs (Pathway vehicle) from every year following construction. The condition survey consisted of a visual inspection and measurement of rut depths using a four foot straightedge. The results are summarized in Table 21.

The condition survey results summarized in Table 21 show very little rutting and only some cracking on these one to two year old projects. Overall the performance at that point was quite good. Photographs taken during the site visits reveal some minor, tight cracks. SR37, SR66 and US231 exhibited minor rutting, mostly located on uphill sections where trucks might travel more slowly. 
Table 212003 Condition survey summary

\begin{tabular}{|l|l|}
\hline Road & Condition Summary \\
\hline SR37 & $1 / 16^{\text {th }}$ inch rut on uphill section, heavy truck traffic, some areas milled for smoothness \\
\hline SR49 & No cracks or ruts, surface good. \\
\hline SR66 & No rut except for one section uphill with $1 / 16^{\text {th }}$ inch rut, no cracks. \\
\hline SR135 & No rut, pavement looks good, low speed area with high traffic volume. \\
\hline SR930 & No ruts, small cracks on edge, surface good. \\
\hline US24 & No ruts, cracking on passing lane, less cracking in driving lane, surface OK. \\
\hline US31i & No ruts, reflective joint cracks. \\
\hline US31k & No ruts, some transverse cracks with heaving, joint popouts, some patching. \\
\hline US50 & No ruts, construction joint cracks. \\
\hline US231 & $1 / 16^{\text {th }}$ inch rut, some longitudinal cracking, some transverse cracks \\
\hline
\end{tabular}

SR32 and US40 were not surveyed.

The Pathway videologs were searched to obtain measured rut depths and International Roughness Index (IRI) data for every year that the pavement sections were surveyed after construction. In some cases, it was possible to verify the beginning and ending reference posts for the project from the videologs because the vehicle passed through the sites while they were under construction. The rut depths and IRI values, which were updated and recorded every mile, were averaged over the length of the project in both directions. (Examination of the data showed the readings were quite consistent in the different directions and were generally quite repeatable from year to year. That is, if a one mile section had a higher IRI one year, it usually had a high IRI during the next survey as well.) A summary of the results is shown in Table 22.

The data in Table 22, collected by the Pathway vehicle, shows how the pavement condition changed over time. Indiana generally considers rut depths less than 0.5 inches and IRI values less than 170 to indicate acceptable performance, as rough guidelines (Jewell Stone, personal communication). All of these pavements exhibit rut depths and IRI values well below these limits. 
Table 22 Summary of pavement condition data from Pathway videologs

\begin{tabular}{|c|c|c|c|c|c|c|c|c|c|c|c|c|c|c|}
\hline \multirow{2}{*}{$\frac{\text { Year }}{\text { Factor }}$} & \multicolumn{2}{|c|}{2002} & \multicolumn{2}{|c|}{2003} & \multicolumn{2}{|c|}{2004} & \multicolumn{2}{|c|}{2005} & \multicolumn{2}{|c|}{2006} & \multicolumn{2}{|c|}{2008} & \multicolumn{2}{|c|}{2009} \\
\hline & IRI & Rut & IRI & Rut & IRI & Rut & IRI & Rut & IRI & Rut & IRI & Rut & IRI & Rut \\
\hline Units & $\mathrm{in} / \mathrm{mi}$ & in & $\mathrm{in} / \mathrm{mi}$ & in & $\mathrm{in} / \mathrm{mi}$ & in & $\mathrm{in} / \mathrm{mi}$ & in & $\mathrm{in} / \mathrm{mi}$ & in & $\mathrm{in} / \mathrm{mi}$ & in & $\mathrm{in} / \mathrm{mi}$ & in \\
\hline SR32 & 40 & 0.06 & -- & -- & 48 & 0.10 & & & 55 & 0.09 & 54 & 0.04 & 59 & 0.04 \\
\hline SR37 & & & 48 & 0.14 & & & 52 & 0.09 & 51 & 0.09 & 57 & 0.08 & 53 & 0.08 \\
\hline SR49 & 68 & 0.14 & & & 70 & 0.12 & & & 66 & 0.08 & 69 & 0.06 & 73 & 0.34 \\
\hline SR66 & & & 58 & 0.10 & & & 60 & 0.06 & 60 & 0.07 & 62 & 0.03 & 64 & 0.03 \\
\hline SR135 & & & 93 & 0.04 & & & 94 & 0.06 & 90 & 0.09 & 105 & 0.06 & 103 & 0.06 \\
\hline SR930 & & & & & 73 & 0.09 & & & 79 & 0.10 & 90 & 0.04 & 99 & 0.04 \\
\hline US24 & & & & & 54 & 0.04 & & & 71 & 0.11 & 65 & 0.04 & 69 & 0.04 \\
\hline US31i & & & 42 & 0.03 & & & 46 & 0.05 & 43 & 0.08 & 64 & 0.04 & 62 & 0.05 \\
\hline US31k & & & & & 51 & 0.09 & & & 67 & 0.10 & 65 & 0.06 & 65 & 0.07 \\
\hline US40 & 51 & 0.04 & & & 60 & 0.08 & & & 70 & 0.08 & 76 & 0.04 & 81 & 0.04 \\
\hline US50 & & & 54 & 0.04 & & & 59 & 0.06 & 56 & 0.09 & 61 & 0.07 & 63 & 0.07 \\
\hline US231 & & & 73 & 0.05 & & & 77 & 0.07 & 78 & 0.10 & 93 & 0.09 & 94 & 0.10 \\
\hline
\end{tabular}

Blank cells indicate no Pathway videolog data was collected on that project that year. Data was collected every other year on non-interstate projects prior to 2006. 
In general terms, the Pathway data shows gradual increases in roughness over time, which would be expected. The pavements with the highest IRI values have been consistent higher over their service lives. For example, SR135 had an IRI of 93 in 2003, increasing to 103 in 2009.

The roughness of a pavement is influenced by many factors, especially those related to construction and the overall pavement design. For example, an overlay of an existing pavement may only afford two opportunities to improve the smoothness when placing the intermediate and surface courses. Apparent improvements in roughness between surveys, such as on US31k between 2006 and 2008, are generally quite small and likely caused by the vehicle taking a slightly different path or changing lanes during the surveys.

The Pathway videolog archives maintained by INDOT do not provide detailed information on cracking. In some cases, cracking can be observed visually but this depends on factors such as lighting and the presence of moisture in the cracks (but dried off the surface of the roadway). In many cases, cracking can be surmised by the obvious presence of crack sealant on the pavement surface. This sealant, however, may extend far beyond the actual crack, so it is not a reliable indicator of the extent of cracking. If extensive cracking were present, especially if it had been present for a number of years, the ride quality would be expected to show some deterioration; i.e. the IRI value would likely increase because of the cracking and subsequent deterioration around the initial crack. Reflective cracking from an underlying concrete pavement would also likely affect the ride quality. The overall good ride quality of these pavements suggests that significant cracking is not an issue for these pavements. This is confirmed, to some extent, by the visual evidence of the videologs.

At first glance, it appears some rut depths improved markedly from one survey to the next. For example, on US24, the rut depth was 0.11 in in 2006 and it was only 0.04 in in 2008 . In cases where this apparent improvement was noted, the videologs were carefully scrutinized to see if any maintenance or preservation technique had been employed to improve the rutting. No such treatment could be identified on any of the pavements. After consultation with Jewell Stone, INDOT Pavement Engineer, a more likely explanation was again slight changes in the path of the Pathway vehicle. She also noted that the readings in 2008 seemed to be anomalous on many roads statewide. The measurements are so small that what appears to be a reduction in the rut depth by half or more (as in the case of US24) is actually only a difference of 7 hundredths of an inch or less than $2 \mathrm{~mm}$. Ignoring these slight inconsistencies, then, the general trend in rut depth is a slight increase from the time of construction.

Overall, the rutting performance is extremely good with 11 of the 12 pavements showing rut depths of 0.10 in $(2.5 \mathrm{~mm})$ or less. The Pathway data for SR49, however, reported an average rut 
depth of 0.34 in $(8.6 \mathrm{~mm})$ in 2009. The rut depth on this pavement had been among the highest since the first measurements by Pathway (0.14 in (3.5 mm) in 2002, for example). But, there was an apparent marked increase in 2009. In order to verify the extent of rutting and look for possible explanations, the site was visited in March 2011. There was no significant rutting observable in the field either visually or using a four foot straightedge. The Pathway data for this project in 2009 is apparently in error; perhaps it is another example of the sometimes anomalous data noted previously by Jewell Stone.

As an overall summary of the field performance, then, these pavements are performing quite well after seven to eight years under varying traffic levels.

\subsubsection{Comparison of Field Performance with Laboratory Test Results}

The IDT results revealed the influence of binder grade on the critical cracking temperature of the mixes; the mix with the PG70-28 binder, the only -28 binder, had the lowest (most negative) critical cracking temperature. The cracking temperature depends on more than just the binder stiffness, however; the strength of the mix is also a factor. All of the mixes tested had strengths greater than $3448 \mathrm{kPa}(500 \mathrm{psi})$ at $-10^{\circ} \mathrm{C}$, which is considered acceptable. Only four of the mixes tested had critical cracking temperatures less than or equal to the low temperature binder grade. All of the mixes had critical cracking temperatures lower than $-16^{\circ} \mathrm{C}$. In short, there were no indications that any of these mixes would be especially prone to thermal cracking. (Reflective and/or fatigue cracking may still occur.)

Based on the SST and Purwheel tests performed in the laboratory, none of these mixtures would be expected to exhibit significant rutting in the field. The frequency sweep test indicated that all of the mixes had moduli greater than 35,000 psi at $40^{\circ} \mathrm{C}$, which signifies excellent resistance to rutting. None of the mixtures did exhibit appreciable rutting in the field. 


\section{PART 2 SUMMARY, RECOMMENDATIONS AND CONCLUSIONS}

Part 1 of this research involved the investigation of two projects to compare the results of different compaction and testing procedures on truck and plate sampled materials. The results of Part 1 showed that there were no significant differences between $\mathrm{G}_{\mathrm{mm}}$ values of plate and truck samples when the vacuum-sealing method is used, although there were some differences when the Rice method was used. In most cases, there were no statistically significant differences between the methods of determining $G_{\mathrm{mb}}$ for samples compacted in different brands of compactors using either plate or truck samples. (The comparison of plate and truck samples was intended only to determine if truck sampling was sufficiently representative of the mixture that it could be used to obtain the relatively large samples needed for this project; plate sampling would mar the surface. It was not intended to investigate the applicability of plate or truck sampling for acceptance testing nor to make any policy recommendations regarding sampling.)

Based on the results of Part 1 of this project, truck sampling was used in Part 2. Specific gravities were again determined with both the conventional and vacuum-sealing methods to allow for more comparison of the methods. One gyratory was chosen for use in Part 2, mainly based on familiarity, not on superior performance.

In Part 2 of this research, asphalt surface mixtures from 12 projects around the state were sampled in 2001 and 2002. Laboratory test results were compared to field performance to see if the results could predict field performance.

The comparison of maximum and bulk specific gravities showed good repeatability (within mixes). No statistically significant differences were observed between the maximum specific gravities determined by the conventional and vacuum -sealing methods. After compaction in the gyratory, the bulk specific gravity was determined using conventional and vacuum-sealing methods. Five of nine mixes showed no significant differences between the two test methods.

Indirect tensile test results suggest that all of the mixes will likely perform adequately in terms of resistance to thermal cracking, based on the mix strengths exceeding the guideline minimum mix strength. The results also show, however, that the mix stiffness has a greater effect on the critical cracking temperature than the mix strength. Mixes with lower stiffness tend to have lower (more negative) critical cracking temperatures. While statistical analysis showed that there were significant differences between mixes with the same binder grade and between mixes designed for different traffic levels, no clear differentiation between the mixes could be determined. Of the 12 mixes studied, only four mixes had critical cracking temperatures less than or equal to their binder low temperature grades. 
Frequency sweep testing in the SST suggests that none of these mixtures would be expected to display significant rutting in the field. Similarly, repeated shear at constant height testing results indicate the mixes would be expected to exhibit fair to excellent resistance to tertiary flow.

Purwheel loaded wheel testing did not produce reliable quantified data because of mechanical and computer equipment problems. The samples tested, however, did not display significant rutting, giving some indication that the four mixes studied would be resistant to rutting.

The field performance of the 12 mixtures tested was very good, overall. Very little rutting has occurred on any of the projects.

The field performance also revealed little severe cracking. While reflective and perhaps other cracking can be observed, the ride quality on all of the roadways is still acceptable (even good in most cases), suggesting that serious deterioration is not yet occurring.

This study is, however, subject to some limitations that may be attributed to long-term evaluations of performance. The Superpave mix design procedure evolved over the course of the project, so mixes designed today may differ somewhat from those designed in 2000-2002. In addition, the shear tests used in this project have largely been superseded by dynamic modulus or flow number testing. (The dynamic modulus is used in the recently implemented MechanisticEmpirical Pavement Design Guide.) Long-term studies are inherently attempts to hit moving targets.

This study also suffers, to an extent, from the fact that none of the mixes studied exhibited poor test results or poor field performance. Thus, seeing differences between the mixes is difficult since all would be expected to perform well. That is one advantage of studies of laboratory mixes; some mixes can be designed to fail or perform poorly without inconveniencing or endangering the travelling public.

In conclusion, then, this study did not, perhaps, entirely succeed in establishing performance bands since all of the mixes performed quite well. The study did, however, show that Superpave mixes can be expected to show reasonably good performance when properly designed and constructed. None of the mixes studied exhibited premature rutting or cracking. No stripping distresses are obvious from surface inspection. All of the pavements have acceptable ride quality (IRI). The results of this study indicate that these mixes, designed in 2000-2002, performed quite well overall. The pavements may be expected to continue to perform for several more years. 


\section{References}

1. Christensen, D. “LTSTRESS”, English units version, May 1997.

2. Anderson, R. M., G. A. Huber, D. Walker, and X. Zhang, "Mixture Testing, Analysis and Field Performance of the Pilot Superpave Projects: The 1992 SPS-9 Mixtures," Asphalt Paving

Technology 2000, Association of Asphalt Paving Technologists, Volume 69, 2000, pp. 177-211.

3. Lee, C-J, T. D. White, T. R. West, "Effect of Fine Aggregate Angularity on Asphalt Mixture Performance," FHWA/INDOT/JTRP-98/20, Joint Transportation Research Program, July 1999. 
APPENDICES 
APPENDIX A

Job Mix Formulae 
Table A1 Job mix formula for US 30 project Part 1

\begin{tabular}{|c|c|}
\hline Road number & US 30 \\
\hline District & LaPorte \\
\hline \multicolumn{2}{|l|}{ Material Sources } \\
\hline \multirow[t]{2}{*}{ Coarse aggregates } & \#11 Dolomite \\
\hline & \#11 blast furnace slag \\
\hline \multirow{2}{*}{ Fine aggregates } & \#24 dol. stone sand \\
\hline & \#23 natural sand \\
\hline PG binder & $76-22$ \\
\hline ESAL & 3.2 million \\
\hline Mixture type & $9.5 \mathrm{~mm}$ surface \\
\hline \multicolumn{2}{|l|}{ Particle Size and Volumetrics } \\
\hline \%passing $12.5 \mathrm{~mm}$ & 100 \\
\hline$\%$ passing $9.5 \mathrm{~mm}$ & 95 \\
\hline$\%$ passing $4.75 \mathrm{~mm}$ & 56 \\
\hline \%passing $2.36 \mathrm{~mm}$ & 45 \\
\hline$\%$ passing $600 \mu \mathrm{m}$ & 22.5 \\
\hline$\%$ passing $75 \mu \mathrm{m}$ & 4.2 \\
\hline Mix temp. min. ${ }^{\circ} \mathrm{C}$ & 162 \\
\hline Mix temp. $\max { }^{\circ} \mathrm{C}$ & 169 \\
\hline RAP \% & 0 \\
\hline $\mathrm{G}_{\mathrm{ab}}$ & 2.639 \\
\hline \multicolumn{2}{|l|}{ Ign. Oven test temp, ${ }^{\circ} \mathrm{C}$} \\
\hline \multicolumn{2}{|l|}{ Ign. Oven calibration factor } \\
\hline Binder \%actual (Ign. Oven) & 5.9 \\
\hline Binder \%extracted & 5.7 \\
\hline MSG $\left(\mathrm{G}_{\mathrm{mm}}\right) ;$ Dryback? & $\mathrm{y}$ \\
\hline $\mathrm{N}_{\text {ini }}$ & 9 \\
\hline $\mathrm{N}_{\mathrm{des}}$ & 125 \\
\hline $\mathrm{N}_{\max }$ & 205 \\
\hline Density, kg/m³ @ $\mathrm{N}_{\mathrm{des}}$ & 2360 \\
\hline $\mathrm{G}_{\mathrm{mb}}$ (meas.) @ $\mathrm{N}_{\max }$ & 2.370 \\
\hline $\mathrm{G}_{\mathrm{mm}}$ (plot/calculated $)$ & 2.458 \\
\hline$\%$ Airvoids @ $\mathrm{N}_{\mathrm{des}}$ & 4.0 \\
\hline VMA @ $\mathrm{N}_{\mathrm{des}}$ & 15.9 \\
\hline VFA @ $\mathrm{N}_{\mathrm{des}}$ & 74.7 \\
\hline Coarse aggregate angularity & 100 \\
\hline Fine aggregate angularity & 47.7 \\
\hline Sand equivalency & 97.6 \\
\hline Dust/Calc. Eff. Asphalt & 0.8 \\
\hline Tensile strength ratio \% & 94.1 \\
\hline
\end{tabular}


Table A2 Job mix formula for US 31 project Part 1

\begin{tabular}{|c|c|}
\hline Road number & US 31 \\
\hline District & Greenfield \\
\hline \multicolumn{2}{|l|}{ Material Sources } \\
\hline \multirow[t]{2}{*}{ Coarse aggregates } & \#11 blast furnace slag \\
\hline & \#11 dolomite \\
\hline \multirow{3}{*}{ Fine aggregates } & \#24 dol. mfg. sand \\
\hline & \#24 limestone mfg. sand \\
\hline & \#24 QA fines mfg. sand \\
\hline PG binder & $764-22$ \\
\hline ESAL & 8.4 million \\
\hline Mixture type & $9.5 \mathrm{~mm}$ surface \\
\hline \multicolumn{2}{|l|}{ Particle Size and Volumetrics } \\
\hline$\%$ passing $12.5 \mathrm{~mm}$ & 100 \\
\hline \%passing $9.5 \mathrm{~mm}$ & 91.2 \\
\hline$\%$ passing $4.75 \mathrm{~mm}$ & 57.8 \\
\hline \%passing $2.36 \mathrm{~mm}$ & 41.6 \\
\hline$\%$ passing $600 \mu \mathrm{m}$ & 16.1 \\
\hline$\%$ passing $75 \mu \mathrm{m}$ & 6.0 \\
\hline Mix temp. $\min .{ }^{\circ} \mathrm{C}$ & 302 \\
\hline Mix temp. $\max { }^{\circ} \mathrm{C}$ & 351 \\
\hline RAP \% & 0 \\
\hline $\mathrm{G}_{\mathrm{ab}}$ & 2.618 \\
\hline Ign. Oven test temp, ${ }^{\circ} \mathrm{C}$ & 482 \\
\hline Ign. Oven calibration factor & 0.91 \\
\hline Binder \%actual (Ign. Oven) & 6.3 \\
\hline Binder \%extracted & 5.9 \\
\hline MSG $\left(\mathrm{G}_{\mathrm{mm}}\right)$; Dryback? & $\mathrm{n}$ \\
\hline $\mathrm{N}_{\mathrm{ini}}$ & 8 \\
\hline $\mathrm{N}_{\text {des }}$ & 100 \\
\hline $\mathrm{N}_{\max }$ & 160 \\
\hline Density, $\mathrm{kg} / \mathrm{m}^{3} @ \mathrm{~N}_{\mathrm{des}}$ & 2353 \\
\hline $\mathrm{G}_{\mathrm{mb}}\left(\right.$ plot/calculated) @ $\mathrm{N}_{\max }$ & 2.390 \\
\hline $\mathrm{G}_{\mathrm{mm}}($ plot/calculated $)$ & 2.451 \\
\hline$\%$ Airvoids @ $\mathrm{N}_{\mathrm{des}}$ & 4.0 \\
\hline VMA @ $\mathrm{N}_{\text {des }}$ & 15.8 \\
\hline VFA@ @ $\mathrm{N}_{\mathrm{des}}$ & 74.7 \\
\hline Coarse aggregate angularity & 100 \\
\hline Fine aggregate angularity & 47.2 \\
\hline Sand equivalency & 83.3 \\
\hline Dust/Calc. Eff. Asphalt & 1.2 \\
\hline Tensile strength ratio \% & 85.8 \\
\hline
\end{tabular}


Table A3 Job mix formula for SR 37 project Part 2, 2001

\begin{tabular}{|c|c|}
\hline Road number & SR 37 \\
\hline District & Vincennes \\
\hline \multicolumn{2}{|l|}{ Material Sources } \\
\hline Coarse aggregates & \#11 dolomite \\
\hline \multirow[t]{2}{*}{ Fine aggregates } & dol. $\mathrm{mfg}$ \\
\hline & QA mfg. \\
\hline PG binder & $64-22$ \\
\hline ESAL & 1.5 million \\
\hline Mixture type & $9.5 \mathrm{~mm}$ surface \\
\hline \multicolumn{2}{|l|}{ Particle Size and Volumetrics } \\
\hline \%passing $12.5 \mathrm{~mm}$ & 100 \\
\hline \%passing $9.5 \mathrm{~mm}$ & 96 \\
\hline$\%$ passing $4.75 \mathrm{~mm}$ & 65 \\
\hline \%passing $2.36 \mathrm{~mm}$ & 46 \\
\hline$\%$ passing $600 \mu \mathrm{m}$ & 20 \\
\hline$\%$ passing $75 \mu \mathrm{m}$ & 5.5 \\
\hline Mix temp. min. ${ }^{\circ} \mathrm{C}$ & 152 \\
\hline Mix temp. $\max { }^{\circ} \mathrm{C}$ & 159 \\
\hline RAP $\%$ & $0 \%$ \\
\hline $\mathrm{G}_{\mathrm{ab}}$ & 2.626 \\
\hline Ign. Oven test temp, ${ }^{\circ} \mathrm{C}$ & $538 \mathrm{C}$ \\
\hline Ign. Oven calibration factor & 0.76 \\
\hline Binder \%actual (Ign. Oven) & 6.2 \\
\hline Binder \%extracted & 5.9 \\
\hline MSG $\left(\mathrm{G}_{\mathrm{mm}}\right)$; Dryback? & no \\
\hline $\mathrm{N}_{\mathrm{ini}}$ & 7 \\
\hline $\mathrm{N}_{\text {des }}$ & 75 \\
\hline $\mathrm{N}_{\max }$ & 115 \\
\hline Density, kg/m $/ \mathrm{m}^{3} @ \mathrm{~N}_{\mathrm{des}}$ & 2.371 \\
\hline $\mathrm{G}_{\mathrm{mb}}$ (plot/calculated)@ $\mathrm{N}_{\mathrm{des}}$ & 2.371 \\
\hline $\mathrm{G}_{\mathrm{mm}}$ (plot/calculated) & 2.471 \\
\hline$\%$ Airvoids@ $\mathrm{N}_{\mathrm{des}}$ & 4 \\
\hline VMA @ $\mathrm{N}_{\mathrm{des}}$ & 15.3 \\
\hline VFA@ $\mathrm{N}_{\mathrm{des}}$ & 73.6 \\
\hline Coarse aggregate angularity & 100 \\
\hline Fine aggregate angularity & 43.5 \\
\hline Sand equivalency & 78 \\
\hline Dust/Calc. Eff. Asphalt & 1.1 \\
\hline Tensile strength ratio $\%$ & 80.7 \\
\hline
\end{tabular}


Table A4 Job mix formula for US 40 project Part 2, 2002

\begin{tabular}{|c|c|}
\hline Road number & US 40 \\
\hline District & Greenfield \\
\hline \multicolumn{2}{|l|}{ Material Sources } \\
\hline \multirow[t]{2}{*}{ Coarse aggregates } & \#9 slag \\
\hline & \#11 dolomite \\
\hline \multirow{3}{*}{ Fine aggregates } & \#24 mfg sand \\
\hline & \#24 mfg sand dolomite \\
\hline & \#15 QA fines \\
\hline PG binder & $64-22$ \\
\hline ESAL & $3-30$ million \\
\hline Mixture type & $12.5 \mathrm{~mm}$ surface \\
\hline \multicolumn{2}{|l|}{ Particle Size and Volumetrics } \\
\hline \%passing $19 \mathrm{~mm}$ & 100 \\
\hline$\%$ passing $12.5 \mathrm{~mm}$ & 92 \\
\hline$\%$ passing $9.5 \mathrm{~mm}$ & 78 \\
\hline \%passing $4.75 \mathrm{~mm}$ & 50 \\
\hline$\%$ passing $2.36 \mathrm{~mm}$ & 33.9 \\
\hline$\%$ passing $600 \mu \mathrm{m}$ & 16 \\
\hline$\%$ passing $75 \mu \mathrm{m}$ & 5.1 \\
\hline Mix temp. min. ${ }^{\circ} \mathrm{C}$ & 138 \\
\hline Mix temp. $\max { }^{\circ} \mathrm{C}$ & 160 \\
\hline RAP $\%$ & 0 \\
\hline $\mathrm{G}_{\mathrm{ab}}$ & 2.55 \\
\hline Ign. Oven test temp, ${ }^{\circ} \mathrm{C}$ & 482 \\
\hline Ign. Oven calibration factor & 0.24 \\
\hline Binder \%actual (Ign. Oven) & 6.2 \\
\hline Binder \% extracted & 5.9 \\
\hline MSG $\left(\mathrm{G}_{\mathrm{mm}}\right)$; Dryback? & yes \\
\hline $\mathrm{N}_{\mathrm{ini}}$ & 8 \\
\hline $\mathrm{N}_{\mathrm{des}}$ & 100 \\
\hline $\mathrm{N}_{\max }$ & 160 \\
\hline Density, $\mathrm{kg} / \mathrm{m}^{3} @ \mathrm{~N}_{\mathrm{des}}$ & 2312 \\
\hline $\mathrm{G}_{\mathrm{mb}}\left(\right.$ plot/calculated) @ $\mathrm{N}_{\mathrm{des}}$ & 2.356 \\
\hline $\mathrm{G}_{\mathrm{mm}}($ plot/calculated $)$ & 2.41 \\
\hline \% Airvoids@ $\mathrm{N}_{\mathrm{des}}$ & 4 \\
\hline VMA@ @ $N_{\text {des }}$ & 14 \\
\hline VFA @ $\mathrm{N}_{\mathrm{des}}$ & 73 \\
\hline Coarse aggregate angularity & 100 \\
\hline Fine aggregate angularity & 47 \\
\hline Sand equivalency & 85 \\
\hline Dust/Calc. Eff. Asphalt & 1.1 \\
\hline Tensile strength ratio $\%$ & 95 \\
\hline
\end{tabular}


Table A5 Job mix formula for US 231 project Part 2, 2001

\begin{tabular}{|c|c|}
\hline Road number & US 231 \\
\hline District & Vincennes \\
\hline \multicolumn{2}{|l|}{ Material Sources } \\
\hline \multirow[t]{2}{*}{ Coarse aggregates } & \#11 dolomite \\
\hline & \#12 dolomite \\
\hline \multirow{2}{*}{ Fine aggregates } & QA fine sand \\
\hline & nat. sand \\
\hline PG binder & $70-22$ \\
\hline ESAL & 2.5 million \\
\hline Mixture type & $9.5 \mathrm{~mm}$ surface \\
\hline \multicolumn{2}{|l|}{ Particle Size and Volumetrics } \\
\hline \%passing $12.5 \mathrm{~mm}$ & 100 \\
\hline \%passing $9.5 \mathrm{~mm}$ & \begin{tabular}{|l|l|}
94.5 \\
\end{tabular} \\
\hline \%passing $4.75 \mathrm{~mm}$ & 58.5 \\
\hline$\%$ passing $2.36 \mathrm{~mm}$ & 32 \\
\hline \%passing $600 \mu \mathrm{m}$ & 18.5 \\
\hline$\%$ passing $75 \mu \mathrm{m}$ & 3.8 \\
\hline Mix temp. min. ${ }^{\circ} \mathrm{C}$ & 140 \\
\hline Mix temp. $\max { }^{\circ} \mathrm{C}$ & 170 \\
\hline RAP \% & 0 \\
\hline $\mathrm{G}_{\mathrm{ab}}$ & 2.608 \\
\hline Ign. Oven test temp, ${ }^{\circ} \mathrm{C}$ & 538 \\
\hline Ign. Oven calibration factor & 0.67 \\
\hline Binder \%actual (Ign. Oven) & 6.1 \\
\hline Binder \%extracted & 5.8 \\
\hline MSG $\left(\mathrm{G}_{\mathrm{mm}}\right)$; Dryback? & no \\
\hline $\mathrm{N}_{\mathrm{ini}}$ & 7 \\
\hline $\mathrm{N}_{\mathrm{des}}$ & 75 \\
\hline$N_{\max }$ & 115 \\
\hline Density, $\mathrm{kg} / \mathrm{m}^{3} @ \mathrm{~N}_{\mathrm{des}}$ & 2358 \\
\hline $\mathrm{G}_{\mathrm{mb}}$ (plot/calculated)@ $\mathrm{N}_{\mathrm{des}}$ & 2.39 \\
\hline $\mathrm{G}_{\mathrm{mm}}$ (plot/calculated $)$ & 2.459 \\
\hline$\%$ Airvoids @ $\mathrm{N}_{\mathrm{des}}$ & \begin{tabular}{|l|l|}
4 \\
\end{tabular} \\
\hline VMA@ @ $\mathrm{N}_{\text {des }}$ & 15 \\
\hline VFA@ $\mathrm{N}_{\mathrm{des}}$ & 72.7 \\
\hline Coarse aggregate angularity & 100 \\
\hline Fine aggregate angularity & 40 \\
\hline Sand equivalency & 92 \\
\hline Dust/Calc. Eff. Asphalt & 0.8 \\
\hline Tensile strength ratio $\%$ & 90 \\
\hline
\end{tabular}


Table A6 Job mix formula for US 50 project Part 2, 2001

\begin{tabular}{|c|c|}
\hline Road number & US 50 \\
\hline District & Seymour \\
\hline \multicolumn{2}{|l|}{ Material Sources } \\
\hline \multirow[t]{2}{*}{ Course aggregates } & \#11 dolomite \\
\hline & \# 24 stone sand \\
\hline \multirow{2}{*}{ Fine aggregates } & \#24 dolomite sand \\
\hline & \# 24 nat. sand \\
\hline PG binder & $70-22$ \\
\hline ESAL & 2 million \\
\hline Mixture type & $9.5 \mathrm{~mm}$ surface \\
\hline \multicolumn{2}{|l|}{ Particle Size and Volumetrics } \\
\hline \%passing $12.5 \mathrm{~mm}$ & 100 \\
\hline$\%$ passing $9.5 \mathrm{~mm}$ & 93 \\
\hline$\%$ passing $4.75 \mathrm{~mm}$ & 66 \\
\hline$\%$ passing $2.36 \mathrm{~mm}$ & 45 \\
\hline$\%$ passing $600 \mu \mathrm{m}$ & 21 \\
\hline \%passing $75 \mu \mathrm{m}$ & 5.2 \\
\hline Mix temp. min. ${ }^{\circ} \mathrm{C}$ & 138 \\
\hline Mix temp. $\max { }^{\circ} \mathrm{C}$ & 166 \\
\hline RAP $\%$ & 0 \\
\hline $\mathrm{G}_{\mathrm{ab}}$ & 2.579 \\
\hline Ign. Oven test temp, ${ }^{\circ} \mathrm{C}$ & 482 \\
\hline \multicolumn{2}{|l|}{ Ign. Oven calibration factor } \\
\hline Binder \%actual (Ign. Oven) & 6.6 \\
\hline Binder \%extracted & 5.6 \\
\hline \multicolumn{2}{|l|}{ MSG $\left(\mathrm{G}_{\mathrm{mm}}\right) ;$ Dryback? } \\
\hline $\mathrm{N}_{\mathrm{ini}}$ & 7 \\
\hline $\mathrm{N}_{\text {des }}$ & 75 \\
\hline $\mathrm{N}_{\max }$ & 115 \\
\hline Density, kg/m³ @ $\mathrm{N}_{\text {des }}$ & 2317 \\
\hline \multicolumn{2}{|l|}{$\mathrm{G}_{\mathrm{mb}}$ (plot/calculated)@ $\mathrm{N}_{\text {des }}$} \\
\hline \multicolumn{2}{|l|}{$\mathrm{G}_{\mathrm{mm}}($ plot/calculated $)$} \\
\hline$\%$ Airvoids @ $\mathrm{N}_{\mathrm{des}}$ & 4 \\
\hline VMA@ $\mathrm{N}_{\mathrm{des}}$ & 16 \\
\hline VFA @ $\mathrm{N}_{\text {des }}$ & 75.9 \\
\hline Coarse aggregate angularity & 100 \\
\hline Fine aggregate angularity & 43 \\
\hline Sand equivalency & 94 \\
\hline Dust/Calc. Eff. Asphalt & 0.9 \\
\hline Tensile strength ratio $\%$ & 82 \\
\hline
\end{tabular}


Table A7 Job mix formula for SR 66 project Part 2, 2002

\begin{tabular}{|c|c|}
\hline Road number & SR 66 \\
\hline District & Vincennes \\
\hline \multicolumn{2}{|l|}{ Material Sources } \\
\hline \multirow[t]{3}{*}{ Coarse aggregates } & \#11 Sandstone \\
\hline & \#11 dolomite \\
\hline & \#12 dolomite \\
\hline \multirow[t]{2}{*}{ Fine aggregates } & QA Mfg sand \\
\hline & QA/asph 2 sand \\
\hline PG binder & $70-22$ \\
\hline ESAL & 6.8 million \\
\hline Mixture type & $9.5 \mathrm{~mm}$ surface \\
\hline \multicolumn{2}{|l|}{ Particle Size and Volumetrics } \\
\hline \%passing $12.5 \mathrm{~mm}$ & 100 \\
\hline$\%$ passing $9.5 \mathrm{~mm}$ & 93 \\
\hline \%passing $4.75 \mathrm{~mm}$ & 54 \\
\hline \%passing $2.36 \mathrm{~mm}$ & 32 \\
\hline$\%$ passing $600 \mu \mathrm{m}$ & 17 \\
\hline$\%$ passing $75 \mu \mathrm{m}$ & 5 \\
\hline Mix temp. min. ${ }^{\circ} \mathrm{C}$ & 164 \\
\hline Mix temp. $\max { }^{\circ} \mathrm{C}$ & 170 \\
\hline RAP \% & 0 \\
\hline $\mathrm{G}_{\mathrm{ab}}$ & 2.62 \\
\hline Ign. Oven test temp, ${ }^{\circ} \mathrm{C}$ & 482 \\
\hline Ign. Oven calibration factor & 0 \\
\hline Binder \%actual (Ign. Oven) & 5.6 \\
\hline Binder \%extracted & 5.4 \\
\hline MSG $\left(\mathrm{G}_{\mathrm{mm}}\right)$; Dryback? & no \\
\hline $\mathrm{N}_{\mathrm{ini}}$ & 8 \\
\hline $\mathrm{N}_{\mathrm{des}}$ & 100 \\
\hline $\mathrm{N}_{\max }$ & 160 \\
\hline Density, $\mathrm{kg} / \mathrm{m}^{3} @ \mathrm{~N}_{\mathrm{des}}$ & 2359 \\
\hline $\mathrm{G}_{\mathrm{mb}}$ (plot/calculated)@ $\mathrm{N}_{\mathrm{des}}$ & 2.388 \\
\hline $\mathrm{G}_{\mathrm{mm}}$ (plot/calculated) & 2.457 \\
\hline$\%$ Airvoids@ $\mathrm{N}_{\mathrm{des}}$ & 4 \\
\hline VMA@ @ $\mathrm{N}_{\mathrm{des}}$ & 15 \\
\hline VFA @ $\mathrm{N}_{\text {des }}$ & 73.6 \\
\hline Coarse aggregate angularity & 100 \\
\hline Fine aggregate angularity & 45.6 \\
\hline Sand equivalency & 89.9 \\
\hline Dust/Calc. Eff. Asphalt & 1.2 \\
\hline Tensile strength ratio $\%$ & 90.5 \\
\hline
\end{tabular}


Table A8 Job mix formula for US 31k project Part 2, 2001

\begin{tabular}{|c|c|}
\hline Road number & US 31 (US31k) \\
\hline District & Greenfield \\
\hline \multicolumn{2}{|l|}{ Material Sources } \\
\hline \multirow[t]{2}{*}{ Coarse aggregates } & \#11,\#12 limestone \\
\hline & \#11 BF slag \\
\hline \multirow{2}{*}{ Fine aggregates } & \#14 dolomite sand \\
\hline & \#23, \#24 nat. sand \\
\hline PG binder & $70-22$ \\
\hline ESAL & 11 million \\
\hline Mixture type & $9.5 \mathrm{~mm}$ surface \\
\hline \multicolumn{2}{|l|}{ Particle Size and Volumetrics } \\
\hline \%passing $12.5 \mathrm{~mm}$ & 100 \\
\hline$\%$ passing $9.5 \mathrm{~mm}$ & 91.2 \\
\hline$\%$ passing $4.75 \mathrm{~mm}$ & 49.7 \\
\hline$\%$ passing $2.36 \mathrm{~mm}$ & 35.4 \\
\hline$\%$ passing $600 \mu \mathrm{m}$ & 15.8 \\
\hline \%passing $75 \mu \mathrm{m}$ & 4.6 \\
\hline Mix temp. min. ${ }^{\circ} \mathrm{C}$ & 148 \\
\hline Mix temp. $\max { }^{\circ} \mathrm{C}$ & 165 \\
\hline RAP \% & 0 \\
\hline $\mathrm{G}_{\mathrm{ab}}$ & 2.482 \\
\hline \multicolumn{2}{|l|}{ Ign. Oven test temp, ${ }^{\circ} \mathrm{C}$} \\
\hline \multicolumn{2}{|l|}{ Ign. Oven calibration factor } \\
\hline Binder \%actual (Ign. Oven) & 7.4 \\
\hline Binder \%extracted & 7.1 \\
\hline MSG $\left(\mathrm{G}_{\mathrm{mm}}\right) ;$ Dryback? & yes \\
\hline $\mathrm{N}_{\mathrm{ini}}$ & 8 \\
\hline $\mathrm{N}_{\text {des }}$ & 100 \\
\hline $\mathrm{N}_{\max }$ & 160 \\
\hline Density, kg/m³ @ $\mathrm{N}_{\text {des }}$ & 2261.7 \\
\hline $\mathrm{G}_{\mathrm{mb}}$ (plot/calculated)@ $\mathrm{N}_{\mathrm{des}}$ & 2.3 \\
\hline $\mathrm{G}_{\mathrm{mm}}($ plot/calculated $)$ & 2.356 \\
\hline$\%$ Airvoids @ $\mathrm{N}_{\mathrm{des}}$ & 4 \\
\hline VMA @ $\mathrm{N}_{\mathrm{des}}$ & 15.5 \\
\hline VFA@ $\mathrm{N}_{\mathrm{des}}$ & 75 \\
\hline Coarse aggregate angularity & 100 \\
\hline Fine aggregate angularity & 45 \\
\hline Sand equivalency & 94.8 \\
\hline Dust/Calc. Eff. Asphalt & 0.9 \\
\hline Tensile strength ratio \% & 80.1 \\
\hline
\end{tabular}


Table A9 Job mix formula for US 31i project Part 2, 2001

\begin{tabular}{|c|c|}
\hline Road number & US 31 (US31i) \\
\hline District & Seymour \\
\hline \multicolumn{2}{|l|}{ Material Sources } \\
\hline \multirow[t]{2}{*}{ Coarse aggregates } & \#11 steel slag \\
\hline & \#11 dolomite \\
\hline \multirow{3}{*}{ Fine aggregates } & \#24 stone sand \\
\hline & dolomite sand \\
\hline & \#24 sand \\
\hline PG binder & $70-22$ \\
\hline ESAL & 20 million \\
\hline Mixture type & $9.5 \mathrm{~mm}$ surface \\
\hline \multicolumn{2}{|l|}{ Particle Size and Volumetrics } \\
\hline \%passing $12.5 \mathrm{~mm}$ & 100 \\
\hline \%passing $9.5 \mathrm{~mm}$ & 91.9 \\
\hline$\%$ passing $4.75 \mathrm{~mm}$ & 56.2 \\
\hline \%passing $2.36 \mathrm{~mm}$ & 42.6 \\
\hline$\%$ passing $600 \mu \mathrm{m}$ & 19.7 \\
\hline$\%$ passing $75 \mu \mathrm{m}$ & 4.5 \\
\hline Mix temp. min. ${ }^{\circ} \mathrm{C}$ & 148 \\
\hline Mix temp. $\max { }^{\circ} \mathrm{C}$ & 165 \\
\hline RAP \% & 0 \\
\hline $\mathrm{G}_{\mathrm{ab}}$ & 2.883 \\
\hline Ign. Oven test temp, ${ }^{\circ} \mathrm{C}$ & 482 \\
\hline \multicolumn{2}{|l|}{ Ign. Oven calibration factor } \\
\hline Binder \%actual (Ign. Oven) & 5.9 \\
\hline Binder \%extracted & 5.4 \\
\hline MSG $\left(\mathrm{G}_{\mathrm{mm}}\right) ;$ Dryback? & no \\
\hline $\mathrm{N}_{\mathrm{ini}}$ & 8 \\
\hline $\mathrm{N}_{\text {des }}$ & 100 \\
\hline $\mathrm{N}_{\max }$ & 160 \\
\hline Density, $\mathrm{kg} / \mathrm{m}^{3} @ \mathrm{~N}_{\mathrm{des}}$ & 2593 \\
\hline \multicolumn{2}{|l|}{$\mathrm{G}_{\mathrm{mb}}\left(\right.$ plot/calculated)@ $\mathrm{N}_{\mathrm{des}}$} \\
\hline \multicolumn{2}{|l|}{$\mathrm{G}_{\mathrm{mm}}($ plot/calculated $)$} \\
\hline \% Airvoids @ $\mathrm{N}_{\mathrm{des}}$ & 4 \\
\hline VMA@ $@ \mathrm{~N}_{\mathrm{des}}$ & 15 \\
\hline VFA@ $\mathrm{N}_{\mathrm{des}}$ & 75 \\
\hline Coarse aggregate angularity & 100 \\
\hline Fine aggregate angularity & 47 \\
\hline Sand equivalency & 89 \\
\hline Dust/Calc. Eff. Asphalt & 1 \\
\hline Tensile strength ratio $\%$ & 80.2 \\
\hline
\end{tabular}


Table A10 Job mix formula for SR 135 project Part 2, 2002

\begin{tabular}{|c|c|}
\hline Road number & SR 135 \\
\hline District & Seymour \\
\hline \multicolumn{2}{|l|}{ Material Sources } \\
\hline \multirow{2}{*}{ Coarse aggregates } & \#11 slag \\
\hline & \#11 limestone \\
\hline \multirow{2}{*}{ Fine aggregates } & \#24 QA dolomite sand \\
\hline & \#23 sand \\
\hline PG binder & $70-22$ \\
\hline ESAL & 20 million \\
\hline Mixture type & $12.5 \mathrm{~mm}$ surface \\
\hline \multicolumn{2}{|l|}{ Particle Size and Volumetrics } \\
\hline \%passing $12.5 \mathrm{~mm}$ & 100 \\
\hline \%passing $9.5 \mathrm{~mm}$ & 91.7 \\
\hline$\%$ passing $4.75 \mathrm{~mm}$ & 55.9 \\
\hline \%passing $2.36 \mathrm{~mm}$ & 41.3 \\
\hline \%passing $600 \mu \mathrm{m}$ & 20.5 \\
\hline \%passing $75 \mu \mathrm{m}$ & 4.4 \\
\hline Mix temp. min. ${ }^{\circ} \mathrm{C}$ & 145 \\
\hline Mix temp. $\max { }^{\circ} \mathrm{C}$ & 165 \\
\hline RAP \% & no \\
\hline $\mathrm{G}_{\mathrm{ab}}$ & 2.583 \\
\hline Ign. Oven test temp, ${ }^{\circ} \mathrm{C}$ & 482 \\
\hline Ign. Oven calibration factor & 0.38 \\
\hline Binder \%actual (Ign. Oven) & 6.4 \\
\hline Binder \%extracted & 6 \\
\hline \multicolumn{2}{|l|}{ MSG $\left(\mathrm{G}_{\mathrm{mm}}\right) ;$ Dryback? } \\
\hline $\mathrm{N}_{\mathrm{ini}}$ & 8 \\
\hline $\mathrm{N}_{\text {des }}$ & 100 \\
\hline $\mathrm{N}_{\max }$ & 160 \\
\hline Density, $\mathrm{kg} / \mathrm{m}^{3} @ \mathrm{~N}_{\mathrm{des}}$ & 2333.6 \\
\hline $\mathrm{G}_{\mathrm{mb}}$ (plot/calculated)@ $\mathrm{N}_{\mathrm{des}}$ & 2.371 \\
\hline $\mathrm{G}_{\mathrm{mm}}$ (plot/calculated $)$ & 2.431 \\
\hline$\%$ Airvoids @ $\mathrm{N}_{\mathrm{des}}$ & 4 \\
\hline VMA@ $@ N_{\text {des }}$ & 15.4 \\
\hline VFA@ $N_{\text {des }}$ & 73.9 \\
\hline Coarse aggregate angularity & 100 \\
\hline Fine aggregate angularity & 45 \\
\hline Sand equivalency & 87.3 \\
\hline Dust/Calc. Eff. Asphalt & 0.9 \\
\hline Tensile strength ratio $\%$ & 89.5 \\
\hline
\end{tabular}


Table A11 Job mix formula for SR 49 project Part 2, 2001

\begin{tabular}{|c|c|}
\hline Road number & SR 49 \\
\hline District & La Porte \\
\hline \multicolumn{2}{|l|}{ Material Sources } \\
\hline \multirow{2}{*}{ Coarse aggregates } & \#11 slag \\
\hline & \#11 stone \\
\hline \multirow{2}{*}{ Fine aggregates } & slag sand \\
\hline & nat. sand \\
\hline PG binder & $70-28$ \\
\hline ESAL & 22 million \\
\hline Mixture type & $9.5 \mathrm{~mm}$ \\
\hline \multicolumn{2}{|l|}{ Particle Size and Volumetrics } \\
\hline \%passing $12.5 \mathrm{~mm}$ & 100 \\
\hline \%passing $9.5 \mathrm{~mm}$ & 92.5 \\
\hline$\%$ passing $4.75 \mathrm{~mm}$ & 55.3 \\
\hline \%passing $2.36 \mathrm{~mm}$ & 41.4 \\
\hline \%passing $600 \mu \mathrm{m}$ & 22.6 \\
\hline \%passing $75 \mu \mathrm{m}$ & 4.5 \\
\hline Mix temp. min. ${ }^{\circ} \mathrm{C}$ & 135 \\
\hline Mix temp. $\max { }^{\circ} \mathrm{C}$ & 165 \\
\hline RAP \% & 0 \\
\hline $\mathrm{G}_{\mathrm{ab}}$ & 2.586 \\
\hline Ign. Oven test temp, ${ }^{\circ} \mathrm{C}$ & 538 \\
\hline Ign. Oven calibration factor & 0.77 \\
\hline Binder \%actual (Ign. Oven) & 6 \\
\hline Binder \%extracted & 5.7 \\
\hline MSG $\left(\mathrm{G}_{\mathrm{mm}}\right) ;$ Dryback? & yes \\
\hline $\mathrm{N}_{\mathrm{ini}}$ & 8 \\
\hline $\mathrm{N}_{\text {des }}$ & 100 \\
\hline $\mathrm{N}_{\max }$ & 160 \\
\hline Density, kg/m³ @ $\mathrm{N}_{\text {des }}$ & 2304 \\
\hline $\mathrm{G}_{\mathrm{mb}}$ (plot/calculated)@ $\mathrm{N}_{\mathrm{des}}$ & 2.326 \\
\hline $\mathrm{G}_{\mathrm{mm}}$ (plot/calculated $)$ & 2.4 \\
\hline$\%$ Airvoids @ $\mathrm{N}_{\mathrm{des}}$ & 4 \\
\hline VMA@ $@ N_{\text {des }}$ & 16.3 \\
\hline VFA@ $N_{\text {des }}$ & 75.4 \\
\hline Coarse aggregate angularity & 100 \\
\hline Fine aggregate angularity & 45.2 \\
\hline Sand equivalency & 90.5 \\
\hline Dust/Calc. Eff. Asphalt & 0.8 \\
\hline Tensile strength ratio $\%$ & 90.9 \\
\hline
\end{tabular}


Table A12 Job mix formula for US 24 project Part 2, 2001

\begin{tabular}{|c|c|}
\hline Road number & US 24 \\
\hline District & Fort Wayne \\
\hline \multicolumn{2}{|l|}{ Material Sources } \\
\hline \multirow[t]{2}{*}{ Coarse aggregates } & 11 BF slag \\
\hline & \#11 dolomite \\
\hline \multirow{2}{*}{ Fine aggregates } & \#24 dolomite stone sand $\mathrm{mfg}$. \\
\hline & $\# 24$ nat. sand \\
\hline PG binder & $76-22$ \\
\hline ESAL & 5.6 million \\
\hline Mixture type & $9.5 \mathrm{~mm}$ mainline \\
\hline \multicolumn{2}{|l|}{ Particle Size and Volumetrics } \\
\hline \%passing $12.5 \mathrm{~mm}$ & 100 \\
\hline \%passing $9.5 \mathrm{~mm}$ & 94 \\
\hline \%passing $4.75 \mathrm{~mm}$ & 55 \\
\hline \%passing $2.36 \mathrm{~mm}$ & 42 \\
\hline$\%$ passing $600 \mu \mathrm{m}$ & 22 \\
\hline \%passing $75 \mu \mathrm{m}$ & 4.5 \\
\hline Mix temp. min. ${ }^{\circ} \mathrm{C}$ & 163 \\
\hline Mix temp. $\max { }^{\circ} \mathrm{C}$ & 168 \\
\hline RAP \% & 0 \\
\hline $\mathrm{G}_{\mathrm{ab}}$ & 2.628 \\
\hline \multicolumn{2}{|l|}{ Ign. Oven test temp, ${ }^{\circ} \mathrm{C}$} \\
\hline \multicolumn{2}{|l|}{ Ign. Oven calibration factor } \\
\hline Binder \%actual (Ign. Oven) & 5.4 \\
\hline Binder \%extracted & 5.1 \\
\hline MSG $\left(\mathrm{G}_{\mathrm{mm}}\right) ;$ Dryback? & yes \\
\hline $\mathrm{N}_{\mathrm{ini}}$ & 8 \\
\hline $\mathrm{N}_{\text {des }}$ & 100 \\
\hline $\mathrm{N}_{\max }$ & 160 \\
\hline \multicolumn{2}{|l|}{ Density, kg/m³@ $\mathrm{N}_{\text {des }}$} \\
\hline $\mathrm{G}_{\mathrm{mb}}\left(\right.$ plot/calculated)@ $\mathrm{N}_{\mathrm{des}}$ & 2.341 \\
\hline $\mathrm{G}_{\mathrm{mm}}$ (plot/calculated) & 2.363 \\
\hline$\%$ Airvoids@ $\mathrm{N}_{\mathrm{des}}$ & 4 \\
\hline VMA@ $\mathrm{N}_{\mathrm{des}}$ & 15 \\
\hline VFA @ $N_{\text {des }}$ & 74.8 \\
\hline Coarse aggregate angularity & 100 \\
\hline Fine aggregate angularity & 46.5 \\
\hline Sand equivalency & 97.6 \\
\hline Dust/Calc. Eff. Asphalt & 0.8 \\
\hline Tensile strength ratio \% & 94.7 \\
\hline
\end{tabular}


Table A13 Job mix formula for SR 32 project Part 2, 2001

\begin{tabular}{|c|c|}
\hline Road number & SR 32 \\
\hline District & Greenfield \\
\hline \multicolumn{2}{|l|}{ Material Sources } \\
\hline \multirow[t]{2}{*}{ Coarse aggregates } & Levy slag \\
\hline & $\# 11$ \\
\hline \multirow{2}{*}{ Fine aggregates } & dolomite sand \\
\hline & nat. sand \\
\hline PG binder & $76-22$ \\
\hline ESAL & 8 million \\
\hline Mixture type & $9.5 \mathrm{~mm}$ surface \\
\hline \multicolumn{2}{|l|}{ Particle Size and Volumetrics } \\
\hline \%passing $12.5 \mathrm{~mm}$ & 100 \\
\hline \%passing $9.5 \mathrm{~mm}$ & 95 \\
\hline \%passing $4.75 \mathrm{~mm}$ & 49 \\
\hline \%passing $2.36 \mathrm{~mm}$ & 38 \\
\hline$\%$ passing $600 \mu \mathrm{m}$ & 20 \\
\hline$\%$ passing $75 \mu \mathrm{m}$ & 4 \\
\hline \multicolumn{2}{|l|}{ Mix temp. min. ${ }^{\circ} \mathrm{C}$} \\
\hline \multicolumn{2}{|l|}{ Mix temp. $\max { }^{\circ} \mathrm{C}$} \\
\hline RAP \% & 0 \\
\hline $\mathrm{G}_{\mathrm{ab}}$ & 2.552 \\
\hline Ign. Oven test temp, ${ }^{\circ} \mathrm{C}$ & 482 \\
\hline \multicolumn{2}{|l|}{ Ign. Oven calibration factor } \\
\hline Binder \%actual (Ign. Oven) & 6.7 \\
\hline Binder \%extracted & 6.3 \\
\hline MSG $\left(\mathrm{G}_{\mathrm{mm}}\right) ;$ Dryback? & no \\
\hline $\mathrm{N}_{\mathrm{ini}}$ & 8 \\
\hline $\mathrm{N}_{\mathrm{des}}$ & 100 \\
\hline $\mathrm{N}_{\max }$ & 160 \\
\hline Density, kg/m³ @ $\mathrm{N}_{\text {des }}$ & 2310 \\
\hline $\mathrm{G}_{\mathrm{mb}}$ (plot/calculated)@ $\mathrm{N}_{\mathrm{des}}$ & 2.341 \\
\hline $\mathrm{G}_{\mathrm{mm}}$ (plot/calculated) & 2.405 \\
\hline$\%$ Airvoids@ $\mathrm{N}_{\mathrm{des}}$ & 4 \\
\hline VMA@ $\mathrm{N}_{\mathrm{des}}$ & 15.6 \\
\hline VFA @ $N_{\text {des }}$ & 74.4 \\
\hline Coarse aggregate angularity & 100 \\
\hline Fine aggregate angularity & 45.3 \\
\hline Sand equivalency & 82.1 \\
\hline Dust/Calc. Eff. Asphalt & 0.8 \\
\hline Tensile strength ratio \% & 97.2 \\
\hline
\end{tabular}


Table A14 Job mix formula for SR 930 project Part 2, 2001

\begin{tabular}{|c|c|}
\hline Road number & SR 930 \\
\hline District & Fort Wayne \\
\hline \multicolumn{2}{|l|}{ Material Sources } \\
\hline \multirow[t]{2}{*}{ Coarse aggregates } & $\# 11$ \\
\hline & \#11 slag \\
\hline \multirow{2}{*}{ Fine aggregates } & \#24 nat. sand \\
\hline & \#24 mfg sand \\
\hline PG binder & $76-22$ \\
\hline ESAL & 35 million \\
\hline Mixture type & $9.5 \mathrm{~mm}$ mainline \\
\hline \multicolumn{2}{|l|}{ Particle Size and Volumetrics } \\
\hline \%passing $12.5 \mathrm{~mm}$ & 100 \\
\hline$\%$ passing $9.5 \mathrm{~mm}$ & 93.3 \\
\hline$\%$ passing $4.75 \mathrm{~mm}$ & 54.9 \\
\hline \%passing $2.36 \mathrm{~mm}$ & 42.7 \\
\hline$\%$ passing $600 \mu \mathrm{m}$ & 20.4 \\
\hline$\%$ passing $75 \mu \mathrm{m}$ & 4.1 \\
\hline Mix temp. $\min .{ }^{\circ} \mathrm{C}$ & 125 \\
\hline Mix temp. $\max { }^{\circ} \mathrm{C}$ & 150 \\
\hline RAP \% & 0 \\
\hline $\mathrm{G}_{\mathrm{ab}}$ & 2.97 \\
\hline \multicolumn{2}{|l|}{ Ign. Oven test temp, ${ }^{\circ} \mathrm{C}$} \\
\hline \multicolumn{2}{|l|}{ Ign. Oven calibration factor } \\
\hline Binder \%actual (Ign. Oven) & 5.5 \\
\hline Binder \%extracted & 5.3 \\
\hline MSG $\left(\mathrm{G}_{\mathrm{mm}}\right)$; Dryback? & no \\
\hline $\mathrm{N}_{\mathrm{ini}}$ & 9 \\
\hline $\mathrm{N}_{\mathrm{des}}$ & 125 \\
\hline $\mathrm{N}_{\max }$ & 205 \\
\hline Density, kg/m $\mathrm{m}^{3} @ \mathrm{~N}_{\text {des }}$ & 2634 \\
\hline $\mathrm{G}_{\mathrm{mb}}\left(\right.$ plot/calculated) @ $\mathrm{N}_{\mathrm{des}}$ & 2.661 \\
\hline $\mathrm{G}_{\mathrm{mm}}($ plot/calculated $)$ & 2.743 \\
\hline \% Airvoids@ $\mathrm{N}_{\mathrm{des}}$ & 4 \\
\hline VMA@ $\mathrm{N}_{\mathrm{des}}$ & 16.2 \\
\hline VFA @ $\mathrm{N}_{\mathrm{des}}$ & 75.3 \\
\hline Coarse aggregate angularity & 100 \\
\hline Fine aggregate angularity & 47.8 \\
\hline Sand equivalency & 90.9 \\
\hline Dust/Calc. Eff. Asphalt & 0.8 \\
\hline Tensile strength ratio $\%$ & 90.9 \\
\hline
\end{tabular}


APPENDIX B

Mixture Volumetrics 
Table B1 Summary of mixture properties from design (DMF) and measured

\begin{tabular}{|c|c|c|c|c|c|c|c|c|c|c|c|c|}
\hline Road & \multicolumn{2}{|c|}{ SR930 } & \multicolumn{2}{|c|}{ SR37 } & \multicolumn{2}{|c|}{ US40 } & \multicolumn{2}{|c|}{ US231 } & \multicolumn{2}{|c|}{ US50 } & \multicolumn{2}{|c|}{ SR 66} \\
\hline NMAS & \multicolumn{2}{|c|}{9.5} & \multicolumn{2}{|c|}{9.5} & \multicolumn{2}{|c|}{12.5} & \multicolumn{2}{|c|}{9.5} & \multicolumn{2}{|c|}{9.5} & \multicolumn{2}{|c|}{9.5} \\
\hline PG & \multicolumn{2}{|c|}{$76-22$} & \multicolumn{2}{|c|}{$64-22$} & \multicolumn{2}{|c|}{$64-22$} & \multicolumn{2}{|c|}{$70-22$} & \multicolumn{2}{|c|}{$70-22$} & \multicolumn{2}{|c|}{$70-22$} \\
\hline ESAL & \multicolumn{2}{|c|}{$35 \mathrm{M}$} & \multicolumn{2}{|c|}{$1.5 \mathrm{M}$} & \multicolumn{2}{|c|}{$3-30 \mathrm{M}$} & \multicolumn{2}{|c|}{$2.5 \mathrm{M}$} & \multicolumn{2}{|c|}{$2 \mathrm{M}$} & \multicolumn{2}{|c|}{$6.8 \mathrm{M}$} \\
\hline Property & DMF & Meas & DMF & Meas & DMF & DMF & DMF & Meas & DMF & Meas & DMF & Meas \\
\hline$P 19.0 \mathrm{~mm}$ & & & & & 100 & & & & & & & \\
\hline P12.5 mm & 100 & 100 & 100 & 100 & 92 & 100 & 100 & 100.0 & 100 & 99.9 & 100 & 100 \\
\hline P9.5 mm & 93.3 & 89.8 & 96 & 96.0 & 78 & 93 & 93 & 96.3 & 93 & 92.5 & 93 & 95.4 \\
\hline P4.75 mm & 54.9 & 54.7 & 65 & 66.5 & 50 & 54 & 54 & 59.1 & 66 & 63.3 & 54 & 59.6 \\
\hline $\begin{array}{l}\text { P2.36 } \\
\text { mm }\end{array}$ & 42.7 & 39.8 & 46 & 46.2 & 33.9 & 32 & 32 & 30.1 & 45 & 46.0 & 32 & 33.2 \\
\hline $\begin{array}{l}\text { P0.600 } \\
\text { mm }\end{array}$ & 20.4 & 17.3 & 20 & 18.9 & 16 & 17 & 17 & 17.0 & 21 & 20.0 & 17 & 16.3 \\
\hline $\begin{array}{l}\text { P0.075 } \\
\text { mm }\end{array}$ & 4.1 & 4.3 & 5.5 & 4.5 & 5.1 & 5.0 & 5.0 & 3.7 & 5.2 & 4.9 & 5.0 & 5.0 \\
\hline $\begin{array}{l}\text { Binder \% } \\
\text { (IO) }\end{array}$ & 5.5 & -- & 6.2 & -- & 6.2 & 5.6 & 5.6 & -- & 6.6 & -- & 5.6 & -- \\
\hline $\begin{array}{l}\text { Binder \% } \\
\text { ext }\end{array}$ & 5.3 & 4.8 & 5.9 & 5.6 & 5.9 & 5.4 & 5.4 & 5.6 & 5.6 & 6.0 & 5.4 & 5.1 \\
\hline$\%$ Air & 4.0 & 3.0 & 4.0 & 5.2 & 4.0 & 4.0 & 4.0 & 4.8 & 4.0 & 4.7 & 4.0 & -- \\
\hline FAA & 47.8 & 44.3 & 43.5 & 44.3 & 47 & 45.6 & 45.6 & 37.5 & 43 & 39.7 & 45.6 & -- \\
\hline
\end{tabular}

DMF $=$ Design Mix Formula

Meas $=$ Measured in the Research Lab

-- Not tested.

Note: Direct comparison of some properties to JMF should be done with caution. For example, air void content was determined on mix samples reheated and compacted in the laboratory, not on plant-compacted specimens. Another example, FAA was measured on extracted aggregate samples, which may have been rounded during the extraction process. 
Table B1 continued

\begin{tabular}{|c|c|c|c|c|c|c|c|c|c|c|c|c|}
\hline Road & \multicolumn{2}{|c|}{ US31k } & \multicolumn{2}{|c|}{ US31i } & \multicolumn{2}{|c|}{ SR135 } & \multicolumn{2}{|c|}{ SR 49} & \multicolumn{2}{|c|}{ US24 } & \multicolumn{2}{|c|}{ SR 32} \\
\hline NMAS & \multicolumn{2}{|c|}{9.5} & \multicolumn{2}{|c|}{9.5} & \multicolumn{2}{|c|}{12.5} & \multicolumn{2}{|c|}{9.5} & \multicolumn{2}{|c|}{9.5} & \multicolumn{2}{|c|}{9.5} \\
\hline PG & \multicolumn{2}{|c|}{$70-22$} & \multicolumn{2}{|c|}{$70-22$} & \multicolumn{2}{|c|}{$70-22$} & \multicolumn{2}{|c|}{$70-28$} & \multicolumn{2}{|c|}{$76-22$} & \multicolumn{2}{|c|}{$76-22$} \\
\hline ESAL & \multicolumn{2}{|c|}{$11 \mathrm{M}$} & \multicolumn{2}{|c|}{$20 \mathrm{M}$} & \multicolumn{2}{|c|}{$20 \mathrm{M}$} & \multicolumn{2}{|c|}{$22 \mathrm{M}$} & \multicolumn{2}{|c|}{$5.6 \mathrm{M}$} & \multicolumn{2}{|c|}{$8 \mathrm{M}$} \\
\hline Property & DMF & Meas & DMF & Meas & DMF & Meas & DMF & Meas & DMF & Meas & DMF & Meas \\
\hline \multicolumn{13}{|l|}{ P19.0 mm } \\
\hline P12.5 mm & 100 & 100 & 100 & 100 & 100 & 100 & 100 & 100 & 100 & 100 & 100 & 100 \\
\hline P9.5 mm & 91.2 & 91.0 & 91.9 & 90.9 & 91.7 & 93.6 & 92.5 & 94.5 & 94 & 92.2 & 95 & 92.7 \\
\hline P4.75 mm & 49.7 & 46.0 & 56.2 & 58.5 & 55.9 & 61.5 & 55.3 & 59.4 & 55 & 55.5 & 49 & 48.4 \\
\hline P2.36 $\mathrm{mm}$ & 35.4 & 31.7 & 42.6 & 45.9 & 41.3 & 44.7 & 41.4 & 41.8 & 42 & 42.5 & 38 & 34.4 \\
\hline $\mathrm{P} 600 \mu \mathrm{m}$ & 15.8 & 11.6 & 19.7 & 20.0 & 20.5 & 19.6 & 22.6 & 23.0 & 22 & 19.4 & 20 & 13.7 \\
\hline P75 $\mu \mathrm{m}$ & 4.6 & 3.9 & 4.5 & 3.9 & 4.4 & 5.8 & 4.5 & 3.8 & 45 & 2.9 & 4 & 1.3 \\
\hline $\begin{array}{l}\text { Binder \% } \\
\text { (IO) }\end{array}$ & 7.4 & -- & 5.9 & -- & 6.4 & -- & 6.0 & -- & 5.4 & -- & 6.7 & -- \\
\hline $\begin{array}{l}\text { Binder \% } \\
\text { ext }\end{array}$ & 7.1 & 6.3 & 5.4 & 5.9 & 6.0 & 6.1 & 5.7 & 5.9 & 5.1 & 4.8 & 6.3 & 5.9 \\
\hline$\%$ Air & 4.0 & 7.1 & 4.0 & 4.4 & 4.0 & -- & 4.0 & 3.8 & 4.0 & 5.9 & 4.0 & 5.5 \\
\hline FAA & 45 & 37.7 & 47 & 48.0 & 45 & -- & 45.2 & 38.0 & 46.5 & 40.5 & 45.3 & 42.5 \\
\hline
\end{tabular}

DMF $=$ Design Mix Formula

Meas $=$ Measured in the Research Lab

-- Not tested.

Binder content according to AASHTO T164

Note: Direct comparison of some properties to JMF should be done with caution. For example, air void content was determined on mix samples reheated and compacted in the laboratory, not on plantcompacted specimens. Another example, FAA was measured on extracted aggregate samples, which may have been rounded during the extraction process. 
APPENDIX C

Purwheel Photos 


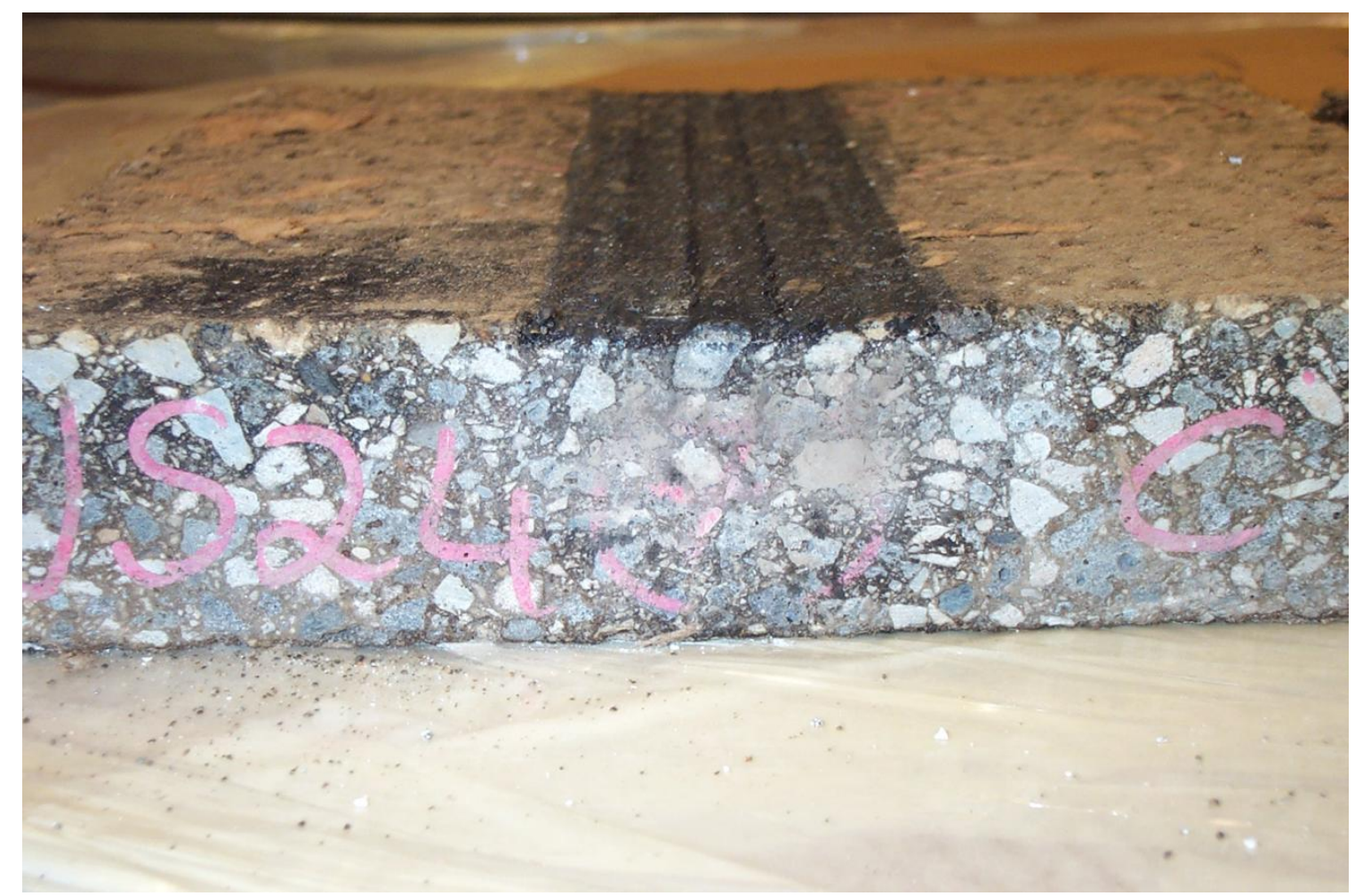

Figure C1 US24 after Purwheel Testing

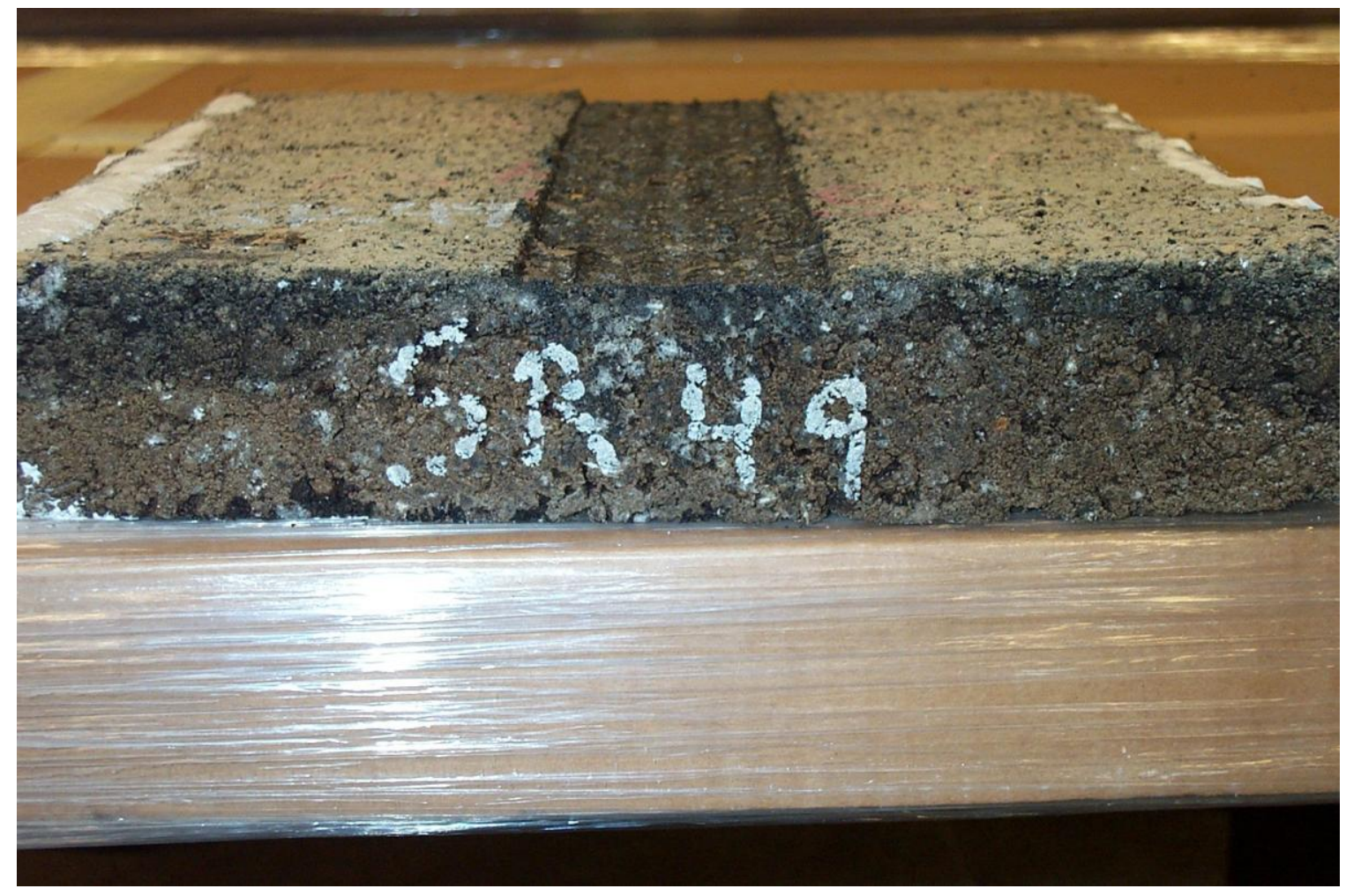

Figure C2 SR 49 after Purwheel Testing 


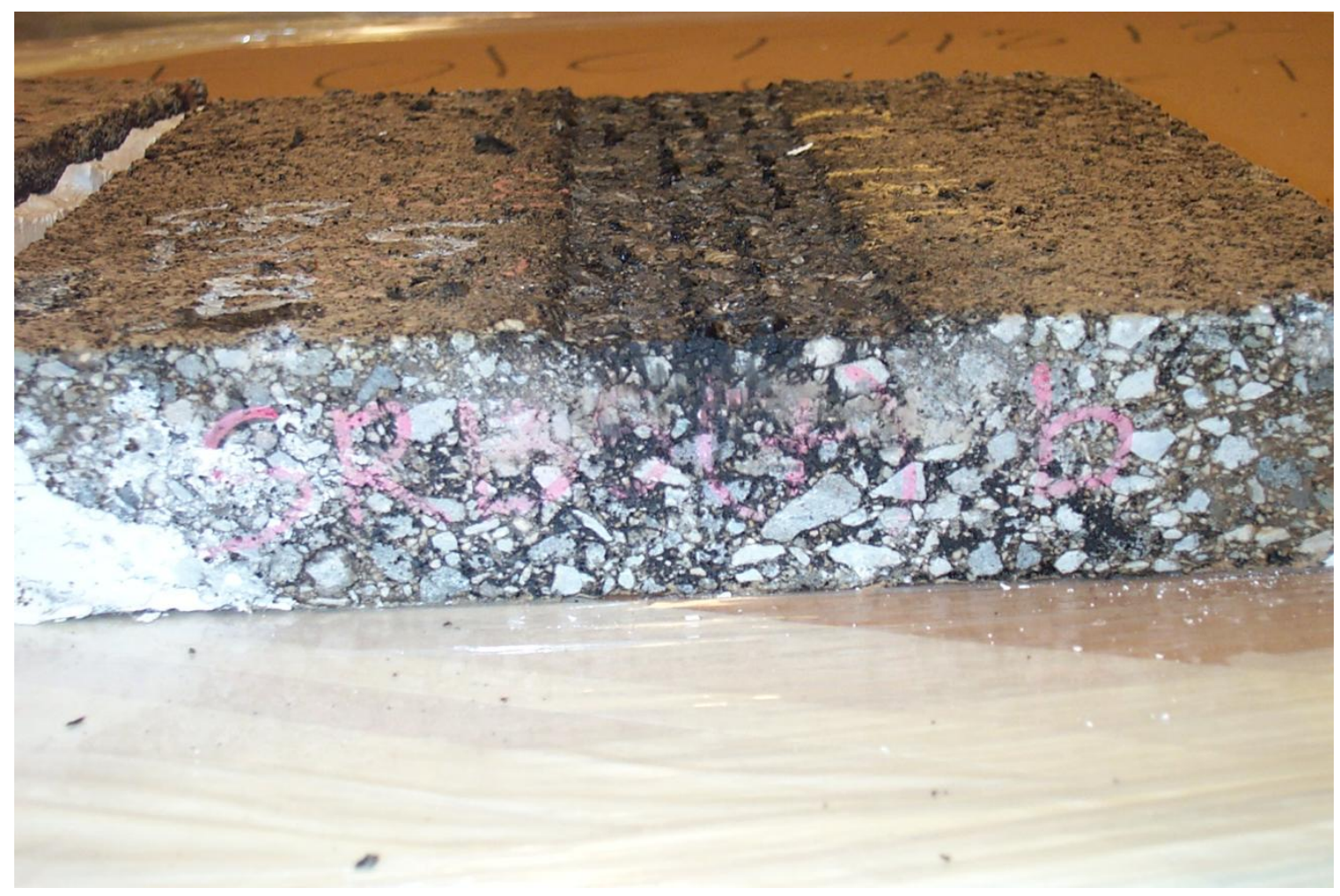

Figure C3 SR135 after Purwheel Testing 